\title{
Effect of solubility limitation on hygroscopic growth and cloud drop activation of SOA particles produced from traffic exhausts
}

\author{
C. Wittbom ${ }^{1,2}$ - A. C. Eriksson ${ }^{3}$ - J. Rissler ${ }^{3,4}$ • P. Roldin ${ }^{1}$ • E. Z. Nordin ${ }^{3,5}$ • S. Sjogren ${ }^{1,6}$ • \\ P. T. Nilsson ${ }^{3}$ - E. Swietlicki ${ }^{1}$ - J. Pagels ${ }^{3}$ - B. Svenningsson ${ }^{1}$
}

Received: 10 February 2018 / Accepted: 25 October 2018 /

Published online: 23 November 2018

(C) The Author(s) 2018

\begin{abstract}
Hygroscopicity measurements of secondary organic aerosol (SOA) particles often show inconsistent results between the supersaturated and subsaturated regimes, with higher activity as cloud condensation nucleus (CCN) than indicated by hygroscopic growth. In this study, we have investigated the discrepancy between the two regimes in the Lund University (LU) smog chamber. Various anthropogenic SOA were produced from mixtures of different precursors: anthropogenic light aromatic precursors (toluene and $m$-xylene), exhaust from a diesel passenger vehicle spiked with the light aromatic precursors, and exhaust from two different gasoline-powered passenger vehicles. Three types of seed particles were used: soot aggregates from a diesel vehicle, soot aggregates from a flame soot generator and ammonium sulphate (AS) particles. The hygroscopicity of seed particles with condensed, photochemically produced, anthropogenic SOA was investigated with respect to critical supersaturation $\left(s_{c}\right)$ and hygroscopic growth factor $(g f)$ at $90 \%$ relative humidity. The hygroscopicity parameter $\kappa$ was calculated for the two regimes: $\kappa_{s c}$ and $\kappa_{g f}$, from measurements of $s_{c}$ and $g f$, respectively. The two $\kappa$ showed significant discrepancies, with a $\kappa_{g f} / \kappa_{s c}$ ratio closest to one for the gasoline experiments with ammonium sulphate seed and lower for the soot seed experiments. Empirical observations of $s_{c}$ and $g f$ were compared to theoretical predictions, using modified Köhler theory where water solubility limitations were taken into account. The results indicate that the inconsistency between measurements in the subsaturated and supersaturated regimes may be explained by part of the organic material in the particles produced from anthropogenic precursors having a limited solubility in water.
\end{abstract}

Keywords Particles $\cdot$ Solubility $\cdot \mathrm{SOA} \cdot$ Hygroscopic growth $\cdot$ Critical supersaturation $\cdot$ Traffic exhausts

Electronic supplementary material The online version of this article (https://doi.org/10.1007/s10874-0189380-5) contains supplementary material, which is available to authorized users.

B. Svenningsson

birgitta.svenningsson@nuclear.lu.se 


\section{Introduction}

The Earth's atmosphere and the global climate are today greatly perturbed by anthropogenic emissions to the air - gases as well as particulates (e.g. IPCC 2014). These emissions themselves further alter both physical and chemical properties of the atmospheric aerosol particles, resulting in altered particle hygroscopic properties - with implications for the climate system. Airborne particles can directly affect our climate by scattering and absorbing incoming solar radiation, and they can also indirectly affect climate by acting as cloud condensation nuclei $(\mathrm{CCN})$, for example by affecting the droplet number concentrations, albedo, precipitation, and persistence of clouds. In the IPCC (2013) report, the former (the direct effect) is referred to as radiative forcing from aerosol-radiation interactions (RFari) and the latter (the indirect effect) as effective radiative forcing from aerosol-cloud interactions (ERFaci). An example of the RFari is that, as primary emission, soot particles emitted from combustion sources such as diesel engines predominantly warm the climate by absorbing light. This ability to absorb light may increase with photochemical processing and water uptake (e.g. Liu et al. 2015; Peng et al. 2016), i.e. as sufficiently thick secondary coatings on soot particles can act as a "lens", thus increasing the mass absorption cross section of the soot core by approximately a factor of 2 . However, also the hygroscopic properties are altered as the soot particles are transformed in the atmosphere by condensation of organic and inorganic material, which enables them to act as CCN (Wittbom et al. 2014). Thus, soot particles can also have an important contribution to the aerosol indirect effect (ERFaci), cooling the climate (Spracklen et al. 2011a).

In addition, aerosol hygroscopicity has an effect on the particle deposition in the human lung. Hence, depending on the hygroscopicity of the particle, the particle will be more or less hazardous to human health. WHO (2016) estimates that $92 \%$ of world's population lives in places where air pollution levels exceed the recommended WHO limits, and that more than 6 million deaths globally are caused by exposure to indoor and outdoor air pollution.

An important observation is that in many locations, organic compounds make up a significant fraction (20-90\%) of the submicron particulate mass (Kanakidou et al. 2005; Jimenez et al. 2009; Cheng et al. 2016; Singh et al. 2017). A substantial part of this organic material is secondary organic aerosol (SOA), formed by condensation of oxidized semi- and low-volatility organic compounds (SVOCs and LVOCs). These often highly oxygenated organic molecules, originate from biogenic and anthropogenic volatile organic compounds (BVOCs and AVOCs) that undergo one or multiple gas-phase oxidation reactions before they become low volatile enough to contribute to the condensed phase organic aerosol (OA) mass (Hallquist et al. 2009). In the atmosphere, the three most important oxidation agents are the hydroxyl radical $(\mathrm{OH})$, ozone $\left(\mathrm{O}_{3}\right)$ and the nitrate radical $\left(\mathrm{NO}_{3}\right) . \mathrm{O}_{3}$ and $\mathrm{NO}_{3}$ can generally only react efficiently with VOCs that contain non-aromatic carbon-carbon double bounds (alkenes and dienes) while $\mathrm{OH}$ also reacts with alkanes and aromatic compounds. The most important BVOCs are alkenes and dienes (isoprene, monoterpenes and sesquiterpenes) (Guenther et al. 2012), while a large fraction of the AVOCs, formed from fossil fuel combustion, are alkanes and aromatic compounds (Schauer et al. 1999, 2002). Thus, while most BVOCs can react with $\mathrm{OH}, \mathrm{O}_{3}$ and $\mathrm{NO}_{3}$, many AVOCs can only be oxidized by $\mathrm{OH}$. SOA produced from biogenic precursors (BSOA) are estimated to make up 50-70\% of the total organic aerosol budget. However, when anthropogenic emissions are present, the estimated BSOA production may be enhanced (Carlton et al. 2010; Spracklen et al. 2011b; Shilling et al. 2013; Budisulistiorini et al. 2015). Furthermore, it has been suggested that in 
the northern midlatitudes, the emissions from anthropogenic sources contribute as much as $50 \%$ to the SOA formation (De Gouw and Jimenez 2009). With respect to the global production of anthropogenic SOA, benzene $\left(\mathrm{C}_{6}\right)$, toluene $\left(\mathrm{C}_{7}\right)$ and xylenes $\left(\mathrm{C}_{8}\right)$ are estimated to be among the important aromatic hydrocarbon precursors (Henze et al. 2008). These three species are commonly found in gasoline exhaust and are also present in diesel exhaust at lower levels (Schauer et al. 1999, 2002; Nordin et al. 2013). It is important to note however that all organic aerosol particle material (both biogenic and anthropogenic) alters the hygroscopic properties of the particle, albeit not to the same extent as inorganic salts. Adequate measures of the hygroscopicity of these compounds and reaction products are therefore needed.

Hygroscopicity of lab-generated or atmospheric aerosol particles is measured either in the subsaturated or supersaturated regime, i.e. at a relative humidity, $\mathrm{RH}<100 \%$ or $\mathrm{RH}>100 \%$, respectively. Results are often presented in terms of either the diameter hygroscopic growth factor $(g f)$ for a given $\mathrm{RH}$, or a specific water vapour supersaturation (i.e. the critical supersaturation, $s_{c}$ ) at which a particle of a given diameter activate into a cloud droplet. Theoretical predictions can either be obtained via Köhler theory, based on chemical composition, to decide the agreement between the two regimes, or the $g f$ may be linked to the $s_{c}$ for a certain particle size, via the hygroscopicity parameter $\kappa$ (Rissler et al. 2006; Petters and Kreidenweis 2007). $\kappa$ represents the number of soluble moles of non-dissociating molecules or ions per unit volume of dry particle (Rissler et al. 2006) and can be used to obtain the volume of water associated with a unit volume of dry particle material at a given water activity. The same definition, but with a different choice of units, is used by Petters and Kreidenweis (2007). $\kappa$ is assumed to be size-independent and constant for particles of a certain chemical composition. Unless it is influenced by surface tension, solubility, or changes in dissociation it is also expected to be the same for different water activities. For example, $\kappa$ ranges from 0.5 to 1.4 for hygroscopic salts, such as ammonium sulphate (AS) or sodium chloride $(\mathrm{NaCl})$, and for non-hygroscopic compounds such as untreated flame generated soot particles (e.g. Henning et al. 2012) or fresh diesel exhaust particles (Wittbom et al. 2014) $\kappa=$ 0 . Organic compounds that are slightly hygroscopic range from $\kappa$ values of 0.01 to very hygroscopic species with a $\kappa$ of almost 0.5 (Petters and Kreidenweis 2007). For photochemically processed diesel exhaust particles, composed of mixtures of soot and soluble secondary aerosol material, $\kappa$ has been reported to be in the range from 0.01 to 0.15 (Tritscher et al. 2011; Wittbom et al. 2014).

Comparison of $\kappa$ derived from measurements in the two saturation-regimes (from the two parameters $s_{c}$ and $g f$ ) of about 25 species was performed by Petters and Kreidenweis (2007). The comparison showed agreement within $30 \%$ for most compounds, but examples where the difference is larger are not hard to find (e.g. Fors et al. 2010; Zhao et al. 2016). Although some of the uncertainties can be attributed to current measurement techniques, the differences in $\kappa$ (between subsaturated and supersaturated conditions) are undoubtedly present. For example, no water uptake is observed in the subsaturated regime for succinic acid (Bilde and Svenningsson 2004; Svenningsson et al. 2006) with $\kappa_{g f}<0.006$, while the $\kappa$-value derived from the supersaturated domain is $>0.1$ (Petters and Kreidenweis 2007). The discrepancy between $\kappa$ values have also been observed for anthropogenic and biogenic aerosol particles, e.g. diesel soot particles and anthropogenic SOA (Tritscher et al. 2011), biogenic SOA (Petters et al. 2009; Wex et al. 2009), biogenic and anthropogenic SOA (Zhao et al. 2015; Zhao et al. 2016), and SOA from biomass burning (Martin et al. 2013). The problem of inconsistency between particle hygroscopicity in the 
subsaturated and supersaturated conditions (e.g. in $\kappa$ values) has previously been examined with regard to an incorrectly-assigned surface tension, bulk-to-surface partitioning of surface-active compounds and solubility limitations (e.g. Bilde and Svenningsson 2004; Wex et al. 2009; Ruehl et al. 2010; Petters and Kreidenweis 2013).

Thus, the discrepancy of particle hygroscopicity between subsaturated and supersaturated conditions of particles containing SOA produced from anthropogenic sources still remains to be solved. Conformable, simple and accurate descriptions of atmospheric aerosol hygroscopicity are needed to better constrain climate models and simulations, and improve predictions for future policymaking.

In this study, we investigate the hygroscopicity of SOA produced from anthropogenic precursors, both at subsaturated and supersaturated conditions. The SOA was produced by photochemical ageing of exhausts from diesel and gasoline cars and/or from light aromatic compounds in the presence of seed particles. The seed particles were either composed of ammonium sulphate (AS) or soot agglomerates from a diesel vehicle or a flame soot generator. In some cases, ammonium nitrate was also produced during the photochemical ageing. Several aspects of the experiments have been published. The SOA production in the gasoline car experiments is described in detail by Nordin et al. (2013) and the cloud droplet formation ability of soot agglomerates in the initial phases of SOA condensation is discussed by Wittbom et al. (2014). The data from these measurements has also been used together with ambient data to discuss time scales for soot transformation from hydrophobic to potential CCN (Eriksson et al. 2017). Modelling of chamber experiments from the same experimental campaign are presented by Roldin et al. (2014), together with comparison with the experimental data.

The focus in the present study is on the hygroscopicity at the late stages of the experiments, when the aerosol is dominated by the SOA and the influence of the seed particles is progressively declining. Using modified Köhler theory, the empirical data of the critical supersaturation $\left(s_{c}\right)$ and growth factor $(g f)$ are compared with theoretical predictions. We evaluate and show that the solubility of the organic fraction in the particle may explain the inconsistency between the measured observation from the subsaturated and supersaturated regimes.

\section{Experimental}

Photochemical processing of anthropogenic volatile organic emissions was performed in the aerosol laboratory smog chamber at Lund University (LU). The smog chamber consists of a $6 \mathrm{~m}^{3}$ teflon/FEP bag in a temperature controlled stainless steel chamber. As instruments consumed air from the smog chamber the floor of the Teflon bag was raised in order to decrease its volume and prevent under-pressure in the bag. Four banks, each consisting of five $100 \mathrm{~W}$ fluorescent blacklights (Cleo performance 100$\mathrm{R}$, Phillips, the Netherlands) were used. The light spectrum ranged from $320 \mathrm{~nm}$ to $380 \mathrm{~nm}$, peaking at about $350 \mathrm{~nm}$. To enhance the radiation uniformity and intensity in the chamber, the walls of the enclosing steel chamber were coated with reflective aluminum foil. The experimental set-up and details of the experiments have been 


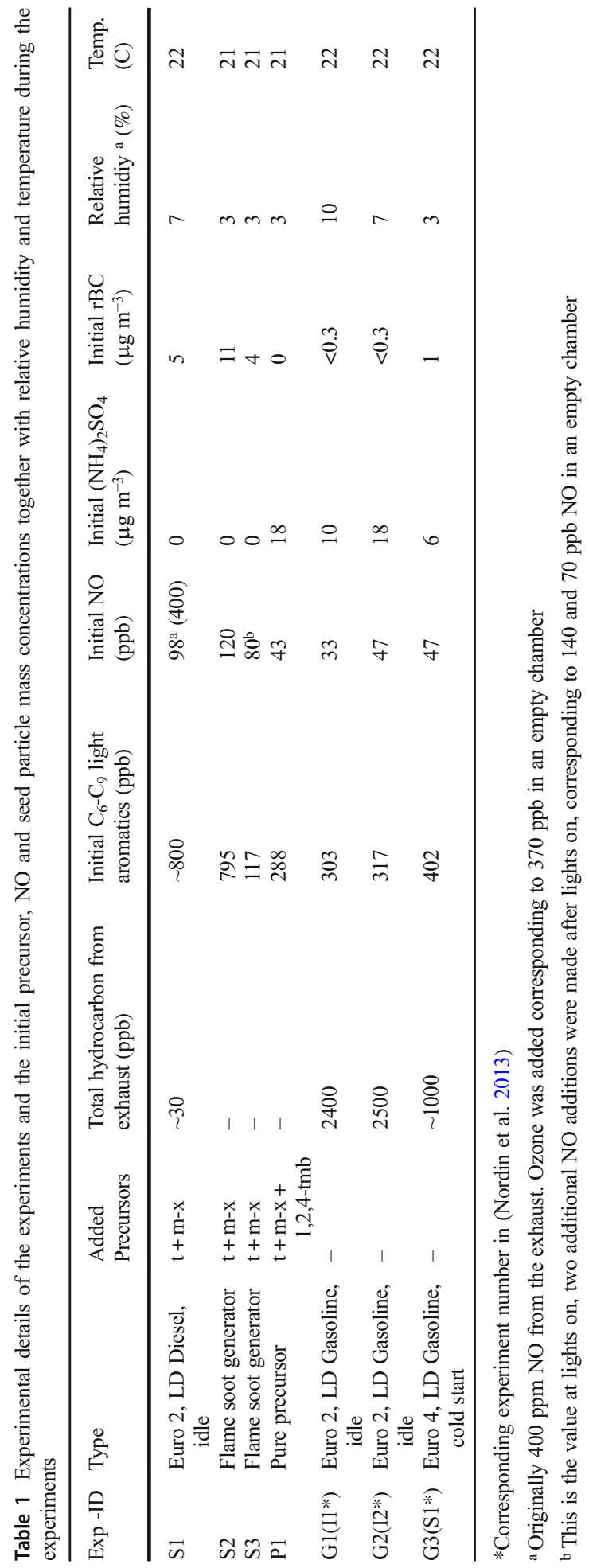


described previously by Nordin et al. (2013) and Wittbom et al. (2014). Here we present results from 7 experiments (listed in Table 1), chosen by coverage in data.

\subsection{Aerosol sources}

To study the influence of anthropogenic volatile organic emissions on SOA hygroscopicity, four different combinations of SOA precursor mixtures were used, listed in Table 1. (1) Selected amounts of toluene and $m$-xylene (at a 2:1 ratio) were added as SOA precursors to the ammonium sulphate seed in the precursor experiment P1, as well as to the three soot experiments (S1, S2, and S3). (2) In one experiment (S1), exhaust from a Euro II diesel passenger vehicle (Rissler et al. 2013; Wittbom et al. 2014) was used in addition to the precursors (toluene and $m$-xylene). Finally, gasoline exhaust with only the complex mixture of precursors originally emitted in the exhaust from (3) one Euro II and (4) one Euro IV gasolinepowered passenger vehicle were used as precursors (experiment G1-G3), described in detail by Nordin et al. (2013).

Two types of seed particles were used to induce condensation of low-volatile reaction products formed from the precursor mixtures onto the particles: (1) soot agglomerates (initially hydrophobic at supersaturation $<2 \%$ ), or ammonium sulphate particles (AS; hygroscopic). The soot agglomerates were produced in two ways: either from the Euro II Diesel vehicle (experiment S1; Rissler et al. 2013; Wittbom et al. 2014) or from a diffusion flame soot generator (Malik et al. 2011) as in experiment S2 and S3. (2) AS particles were used as seeds for inducing condensation of vapours formed in the exhausts of the two gasoline vehicles (experiments G1-G3) as well as in the pure precursor experiment (P1). The polydisperse AS aerosol was generated using a nebuliser (Collison type, Topas Gmbh, Germany) and was introduced into the chamber after passing a silica diffusion drier and a ${ }^{63} \mathrm{Ni}$ bipolar charger (for more details see Nordin et al. 2013).

The exhaust was injected into the initially clean smog chamber (particle number and volume concentrations $<100 \mathrm{~cm}^{-3}$ and $<0.01 \mu \mathrm{g} \mathrm{m}^{-3}$, respectively), with a primary dilution ratio of 4-5.

The total dilution ratios finally achieved in the Teflon chamber were: for the diesel vehicle $\sim 350$, for the flame soot generator 50-100 and for the gasoline vehicles 30-110 (apart from experiment $\mathrm{G} 3$ which was a cold start experiment with very high emissions, where the dilution ratio was 1600). The $\mathrm{S}$ experiments resulted in initial number concentrations of 6000 $12,000 \mathrm{~cm}^{-3}$ and particle mass concentrations of 4-11 $\mu \mathrm{g} \mathrm{m}^{-3}$ from the diesel exhaust and the flame soot generator emissions, while the $\mathrm{G}$ and $\mathrm{P}$ experiments had initial number concentrations of the AS seed aerosol of 20,000-25,000 $\mathrm{cm}^{-3}$ and corresponding mass concentrations of 6-18 $\mu \mathrm{g} \mathrm{m}^{-3}$.

The gasoline exhaust and precursor experiments were carried out at initial light aromatics (LA; C6-C9) to nitrogen oxide (NO) ratios of 7 to 9. The NO emissions from the diesel vehicle were very high, with a level in the chamber after exhaust injection of $\sim 400 \mathrm{ppb}$. Ozone was used to convert a majority of $\mathrm{NO}$ to nitrogen dioxide $\left(\mathrm{NO}_{2}\right)$. After spiking with toluene and $m$ xylene the LA to NO ratios in the diesel exhaust and flame generated soot experiments were 78 in experiment $\mathrm{S} 1$ and $\mathrm{S} 2$ and 1.5 in experiment S3. At the onset of UV radiation, the NO concentration was $30-50 \mathrm{ppb}$ in the $\mathrm{G}$ and $\mathrm{P}$ experiments and $80-120 \mathrm{ppb}$ in the $\mathrm{S}$ experiments. LA was $200-400 \mathrm{ppb}$ in all $\mathrm{G}$ and P experiments, $\sim 800 \mathrm{ppb}$ in experiment $\mathrm{S} 1$ and $\mathrm{S} 2$ and $\sim 120 \mathrm{ppb}$ in $\mathrm{S} 3$. 


\subsection{Instrumentation}

The transformation in hygroscopic properties of the aerosol particles at subsaturated conditions was monitored using a hygroscopicity tandem differential mobility analyser (H-TDMA, Nilsson et al. 2009). In principle, the first differential mobility analyser (DMA) enables size selection of the dry aerosol particles according to the mobility diameter $\left(d_{z}\right)$. To ensure dry state measurements during the size selection during the experiments presented here, the RH was kept below $23 \%$ and $11 \%$ for the soot and AS seed experiments, respectively. Thereafter, the dry, quasi-monodisperse aerosol is exposed to an increased RH in a conditioning unit. The second DMA and the condensation particle counter (CPC) finally measure the mean diameter $(d(R H))$ of the conditioned aerosol size distribution, and the hygroscopic growth $(g f=d(R H) /$ $d_{d r y}$, where $d_{d r y}=d_{z}$ see Section 3) can be determined. In this study, the RH was set to $90 \%$ in the second DMA (Nilsson et al. 2009). The residence times between the two DMA's and after the humidifier to DMA2 were $\sim 1.4$ and $\sim 0.5 \mathrm{~s}$, respectively. The sheath/aerosol flow rate relationships were 10.0/1.7 and 8.5/0.5 (flows in the unit $\mathrm{dm}^{3} \mathrm{~min}^{-1}$ ), for DMA1 and DMA2, respectively. The residence time in DMA1 was $\sim 2.2 \mathrm{~s}$ and in DMA2 the residence time was about $5.2 \mathrm{~s}$. The time resolution for the measurement of one dry size was approximately $270 \mathrm{~s}$, and depending on number of sizes measured, the time resolution between measurements for a certain size during an experiment differed between 270 to $810 \mathrm{~s}$. More details regarding the instrument are described by Nilsson et al. (2009) and Fors et al. (2011).

At supersaturated conditions, the aerosol particle critical supersaturations $\left(s_{c}\right)$ were measured using two continuous-flow streamwise thermal-gradient CCN counters (CFSTGC from DMT, CCNC-100, Roberts and Nenes 2005; Lance et al. 2006) operating according to the Scanning Flow CCN Analysis procedure introduced by Moore and Nenes (2009). In short, the dry, quasi-monodisperse aerosol (pre-size selected using a DMA as described for the $\mathrm{H}$ TDMA) is conditioned in a continually wetted vertical column. Here, the flow in the column is varied in a controlled manner (between 0.2 and $1 \mathrm{dm}^{3} \mathrm{~min}^{-1}$ ), while the streamwise temperature gradient $(\Delta T)$ and pressure $(P)$ is maintained constant. Three temperature gradients $(\Delta T=18,10$, and $4 \mathrm{~K})$ were used to capture the full range of changes in hygroscopicity of the ageing particles. By increasing the flow rate, supersaturation increases (for further information see Moore and Nenes 2009; Wittbom et al. 2014). The supersaturation ranges calibrated for these three temperature gradients overlapped: $0.09-0.37,0.34-0.98,0.63-$ $1.57 \%$, for $\Delta T=4,10$, and $18 \mathrm{~K}$. The two CCNC ran in parallel with inverse scan cycles, with one instrument at maximum flow rate while the other at minimum (for $20 \mathrm{~s}$ ) and with linear decreasing/increasing flow rates (for $120 \mathrm{~s}$ ). Consequently, the time resolution for a supersaturation of one particle size was $280 \mathrm{~s}$. More details of the instrumental set up are described by Wittbom et al. (2014).

An online Aerodyne high-resolution time-of-flight mass spectrometer (HR-ToF-AMS, Aerodyne Research) was used for determining the chemical composition of the nonrefractory species (i.e. the AS and organic aerosol, OA) in the particles, as described by Wittbom et al. (2014). A $1064 \mathrm{~nm}$ laser vaporiser was added to the instrument enabling detection of refractory black carbon ( $\mathrm{rBC})$, and the instrument is then referred to as the Soot Particle Aerosol Mass Spectrometer (SP-AMS, Aerodyne Research). The tungsten vaporiser in the AMS was engaged continuously, while the laser (SP-AMS) operated in 5 min intervals every hour. Detailed descriptions of both instruments are found elsewhere (DeCarlo et al. 2006; Onasch et al. 2012). 
To monitor the alteration in mass of individual particles due to condensation of organic compounds, nitric acid and ammonia, an Aerosol Particle Mass Analyzer was utilized after size selection by a DMA (DMA-APM, McMurry et al. 2002; Kanomax Japan 3600). In between the DMA and APM, a thermodenuder was introduced, hence a DMA-(TD)-APM (Rissler et al. 2013). The TD temperature was set to $300{ }^{\circ} \mathrm{C}$ and $100{ }^{\circ} \mathrm{C}$ when soot and AS was used as seed aerosol, respectively. AS evaporates at around $150^{\circ} \mathrm{C}$ in this TD and evaporation of AS at $100{ }^{\circ} \mathrm{C}$ was insignificant. The mass fraction of volatile material for selected sizes was quantified using the same approach as used by Pagels et al. (2009), i.e. by comparing measurements with and without the thermodenuder.

The particle number size distribution (in the range $d_{z}=10-600 \mathrm{~nm}$ ) was measured using a custom-built scanning mobility particle sizer (SMPS, Löndahl et al. 2008). In short, the system consists of a ${ }^{63} \mathrm{Ni}$ bipolar charger, a DMA (Vienna, $0.28 \mathrm{~cm}$ long) that scans over the size range, and the particles are then counted using a condensation particle counter (CPC, model 3010, TSI Inc., USA). The sheath/aerosol flow rate relationship was 4.9/0.7 $\mathrm{dm}^{3} \mathrm{~min}^{-1}$.

$\mathrm{NO}, \mathrm{NO}_{2}, \mathrm{O}_{3}, \mathrm{RH}$, temperature, and differential pressure were continuously monitored in the chamber throughout the experiments. Also, in selected experiments, time-resolved light aromatic compounds and other selected VOC concentrations were monitored using a Proton Transfer Reaction Mass Spectrometer (PTR-MS, Ionicon Analytic GmbH, Austria). Nordin et al. (2013) give a more detailed description of the gas monitoring instruments as well as the SMPS.

\section{Data analysis/ theory}

\subsection{Köhler theory}

In this study we have used traditional Köhler theory and k-Köhler theory (Rissler et al. 2006; Petters and Kreidenweis 2007) as described in the Online Resource 1. In addition we have used a modified Köhler theory, outlined below, to take into account compounds with limited solubility, i.e. part of the material is not dissolved during activation.

The water vapour uptake of a particle may be altered if material with limited water solubility is present. To account for such behaviour a modified Köhler equation may be used, altering the shape of the Köhler curve (e.g. Shulman et al. 1996; Bilde and Svenningsson 2004; Huff Hartz et al. 2005). Here, a modified version of the traditional equilibrium Köhler theory is adopted from Bilde and Svenningsson (2004). For simplicity, we assume part of the organic fraction (component 1) to be infinitely soluble in water, while the other part (component 2) has limited water solubility, i.e. the water solubility of the component limits the number of moles dissolved in the droplet solution. This means that undissolved organic material is present in the core until enough water has condensed on the particle to form a saturated solution of component 2, with all of it dissolved. In reality, the two components represent many different organic compounds with different solubilities, which are hard to determine experimentally. The number of dissolved moles ( $n_{s s}$ in Eq. S2, in the Online Resource 1) can then be determined by:

$$
n_{s s}=\min \left\{\frac{\left(D^{3}-d_{d r y^{3}}\right)^{3} C_{s a t, s s}}{M_{s s}} \mid \frac{\beta_{s s} \rho_{0} d_{d r y}{ }^{3}}{M_{s s}}\right\}\left(\frac{\pi}{6}\right)
$$


Here, $d_{d r y}$ is the dry particle diameter. $\beta_{s s}$ is the mass fraction and $M_{s s}$ is the molar mass of compound $s s$ in the initial dry particle. $C_{s a t, s s}$ is the solubility (mass per volume) of compound ss in water. The density $\left(\rho_{0}\right)$ of the dry particle, assuming volume additivity, is given by

$$
\frac{1}{\rho_{0}}=\sum_{s s} \frac{\beta_{s s}}{\rho_{s s}},
$$

where $\rho_{s s}$ is the density of compound ss. When enough water has condensed on the particle to dissolve all organic material, Eq. S2 with $n_{s s}$ from Eq. 1 is equal to traditional Köhler theory.

In Fig. 1a-f, we illustrate Köhler curves modified to take account of limited solubility for a soot particle $\left(\mathrm{S} 1, d_{z}=150 \mathrm{~nm}\right)$ with an organic mass fraction of $\mathrm{mf}_{\text {org }}=0.91$. Here, two scenarios are shown: (a-c) the solubility of compound 2 is varied $\left(C_{\text {sat, } 2}=5,10,15\right.$ and $\left.1000 \mathrm{~g} \mathrm{l}^{-1}\right)$ while the mass fraction of compound 2 is kept constant $\left(\beta_{2}=0.44\right)$, and $(\mathrm{d}-\mathrm{f})$ the organic fraction with a limited solubility is varied $\left(\beta_{2}=0.2,0.4,0.6\right.$ and 0.8$)$ while the solubility of compound 2 is kept constant $\left(C_{s a t, 2}=10 \mathrm{~g} \mathrm{l}^{-1}\right)$. The other part of the organic material (compound 1) has unlimited solubility $\left(C_{\text {sat, },}=\infty\right)$. The modified Köhler equation predicts two maxima for supersaturation as a function of droplet diameter in some of the cases. In the cusp between the two maxima, all organic material is dissolved. Consequently, to the left of the cusp, where the first $s_{c}$ maximum is found, part of the organic material with solubility limitations (compound 2) has not dissolved. In some cases, the first maximum constitutes an activation barrier, which can either depend on $C_{s a t, 2}$ or $\beta_{2}$. When $\beta_{2}$ is kept constant and $C_{s a t, 2}$ is varied in the range $5-15 \mathrm{~g} \mathrm{l}^{-1}$, the $g f$ is not affected (Fig. 1c), since the amount of compound 2 dissolved is too small to affect the water uptake. Nevertheless, for high values of $C_{s a t, 2}$ the droplet growth follows traditional Köhler theory in the supersaturated regime, while in the subsaturated regime the dissolving of compound 2 is seen as an increased $g f$ around and above
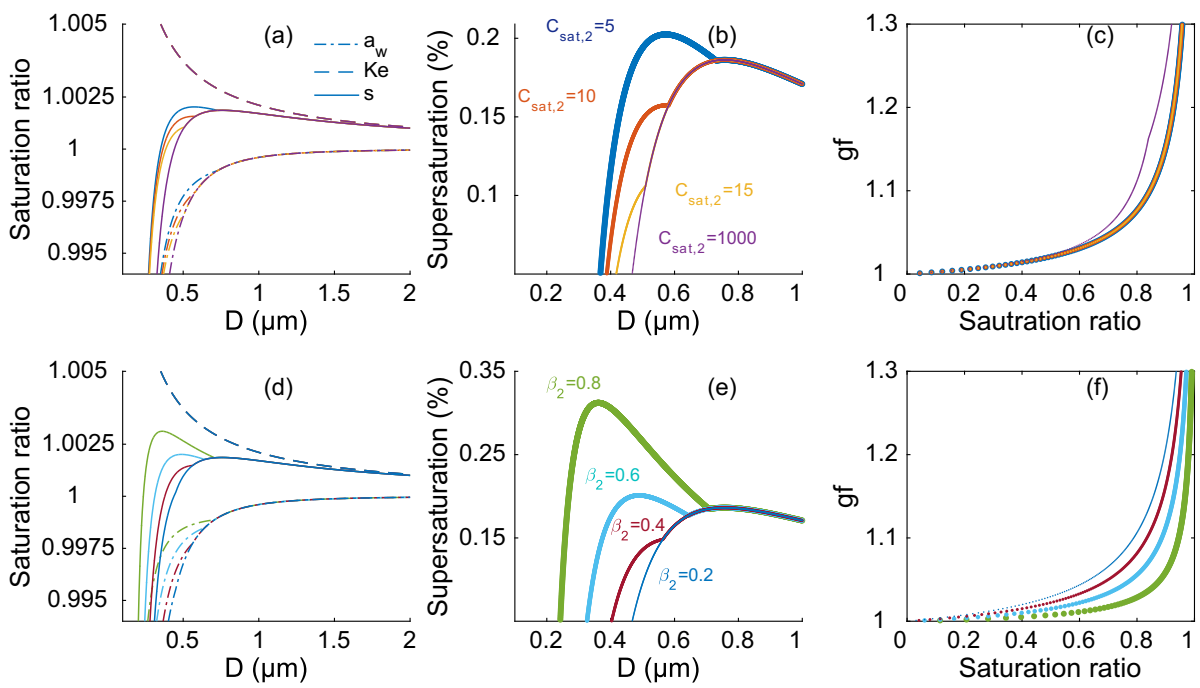

Fig. 1 Examples of Köhler curves modified to take account of limited water solubility of the organic fraction, for a soot particle with $d_{d r y}=150 \mathrm{~nm}$ and $\mathrm{mf}_{\text {org }}=0.91$. In $(\mathbf{a}-\mathbf{c})$, the solubility is varied $\left(C_{s a t, 2}=5,10,15,1000 \mathrm{~g}^{-1}\right.$, blue, orange, yellow and purple line, respectively) and $\beta_{2}=0.44$. In $(\mathbf{d}-\mathbf{f})$, the fraction of $\mathrm{mf}_{\text {org }}$ with limited solubility is varied $\left(\beta_{2}=0.2,0.4,0.6,0.8\right.$, blue, red, turquoise, and green line, respectively) and $C_{\text {sat }, 2}=10 \mathrm{~g} \mathrm{1^{-1 }}$. The water activity $\left(a_{w} ;\right.$ dash/dot), the Kelvin effect $\left(K e\right.$; dash) and saturation ratio $\left(s=a_{w} * K e\right.$; line $)$ as a function of droplet diameter $(D)$ is illustrated in (a) and (d). The supersaturation $(\%)$ as a function of $D$ is illustrated in (b) and (e). The growth factor $(g f)$ as a function of saturation ratio is shown in (c) and (f) 
its deliquescence point. This effect is exemplified by setting the solubility to a high value $\left(C_{s a t, 2}=1000 \mathrm{~g} \mathrm{l}^{-1}\right)$, the purple line in Fig. 1b, c.

In Fig. 1d-f, $C_{s a t, 2}$ is instead kept constant $\left(C_{s a t, 2}=10 \mathrm{~g} \mathrm{l}^{-1}\right)$ and the mass fraction of compound $2\left(\beta_{2}\right)$ is varied. In this case both the $s_{c}$ and the $g f$ are affected. In the supersaturated regime, the droplets experience the same activation barrier as in the former example. In this case, however, there is a difference also in the $g f$ at subsaturation. Hence, both the mass fraction of compound $2\left(\beta_{2}\right)$ and the solubility $\left(C_{s a t, 2}\right)$ of this fraction of the organic material are of importance when evaluating empirical hygroscopicity data of particles with solubilitylimited material in the two regimes (subsaturation and supersaturation).

\subsection{Chemical overview and input values for Köhler calculations}

To perform calculations of the particle hygroscopicity by means of Köhler-theory, knowledge of parameters depending on particle chemical composition is necessary. In this section, we present how these input values were obtained. More information about the aerosol characterisation and modelling during this experiment is found in the Online Resource 1 as well as in the work by Nordin et al. (2013) and Wittbom et al. (2014).

The organic and soot mass fractions $\left(\mathrm{mf}_{\text {org }}\right.$ and $\left.\mathrm{mf}_{\mathrm{BC}}\right)$ of the particles in the soot experiments (S1, S2 and S3) were derived from direct measurements of the relationship between mobility diameter and particle mass, using the DMA-(TD)-APM set-up with and without the thermodenuder. Further details are found elsewhere (Wittbom et al. 2014). The time resolution of the DMA-(TD)-APM measurements was on average $30 \mathrm{~min}$. To gain a better time resolution for the Köhler modelling, a best fit was applied to empirical time series.

Due to the non-sphericity and restructuring of soot agglomerates during photochemical processing, there is a possibility that a systematic error is introduced when the mobility diameter is used as the dry diameter for Köhler-theory predictions of hygroscopicity, as discussed by others (e.g. Khalizov et al. 2009; Tritscher et al. 2011; Henning et al. 2012; Rissler et al. 2012; Wittbom et al. 2014). Also, due to a restructuring of the particles during humidification inside the H-TDMA, in some cases the measured $g f$ shows values below one. With respect to $s_{c}$, the prediction errors can be accounted for by a conversion from the mobility diameter $\left(d_{z}\right)$ to the volume equivalent diameter $\left(d_{v e}\right)$. However, as the $\mathrm{mf}_{\text {org }}$ increases, the two diameters, $d_{z}$ and $d_{v e}$, approach the same value. In this study, data of particles with a difference of less than $3 \%$ or smaller between the mobility and volume equivalent diameters $\left(\left(1-d_{z}\right) / d_{v e}\right)$ was used, corresponding to an $\mathrm{mf}_{\text {org }}$ of 0.76 or higher (size dependent). This difference in size of less than $3 \%$ is within the measurement error. At this level of $\mathrm{mf}_{\text {org }}$, the soot particles have already restructured into a more spherical-like shape, i.e. $d_{z}$ is approaching $d_{v e}$. Thus, the prediction error was small and the measured $g f$ was larger than 1 (this is further discussed in Section 5 in the Online resource 1). Hence, in this study the $d_{z}$ was used as $d_{d r y}$

The carbon mean oxidation state for the SOA in the soot seeded experiments was stable during the hygroscopicity measurements reported here. A time series of this, together with a mass spectrum is presented in the Online Resource 1, fig. S1.

For the gasoline and precursor experiments (G1-G3, P1), the organic aerosol, ammonium sulphate (AS) and ammonium nitrate (AN) mass fractions $\left(\mathrm{mf}_{\text {org }}, \mathrm{mf}_{\mathrm{AS}}\right.$ and $\mathrm{mf}_{\mathrm{AN}}$, respectively) were modelled using the Aerosol Dynamics, gas- and particle-phase chemistry model for laboratory CHAMber studies (ADCHAM; Roldin et al. 2014). The model was used as a sophisticated tool to estimate the particle size dependent chemical composition based on the observed particle number size distribution evolution and total particulate mass of organics, 
nitrate, ammonium and sulphate (additional information is given in Online Resource 1). Ammonia $\left(\mathrm{NH}_{3}\right)$ forms in the three-way catalyst of the gasoline vehicles and reacts with nitric acid $\left(\mathrm{HNO}_{3}\right)$, which forms from reactions between nitrogen dioxide $\left(\mathrm{NO}_{2}\right)$ and $\mathrm{OH}$ in the chamber. $\mathrm{HNO}_{3}$ and $\mathrm{NH}_{3}$ were co-condensing with organic compounds on the seed particles in two of the gasoline experiments (G1 and G2). No detectable amounts of AN were formed in the cold start and precursor experiments, presumably due to very low ammonia emissions. In the cold start experiment (G3), the temperature of the catalyst was likely too low to give ammonia emissions. Due to the seed particle material choice (AS, experiment G1-G3 and P1), measurements using the DMA-(TD)-APM cannot be accomplished in the same way as for the soot particles (experiments S1-S3). The AS starts evaporating at low temperatures (about $150{ }^{\circ} \mathrm{C}$ ), while some of the organics may still be left in the particle phase (Fig. S11, Online Resource 1). Furthermore, this method cannot separate the organic coating material from the $\mathrm{AN}$ in the $\mathrm{G}$ experiments. Hence, the mass fractions of different compounds cannot be fully distinguished. Therefore, the mass fractions were instead modelled, see Fig. 2. A description of the ADCHAM modelling setup is found in Online Resource 1, together with time series of major chemical components from modelling and measurements (Online Resource 1, section 3).
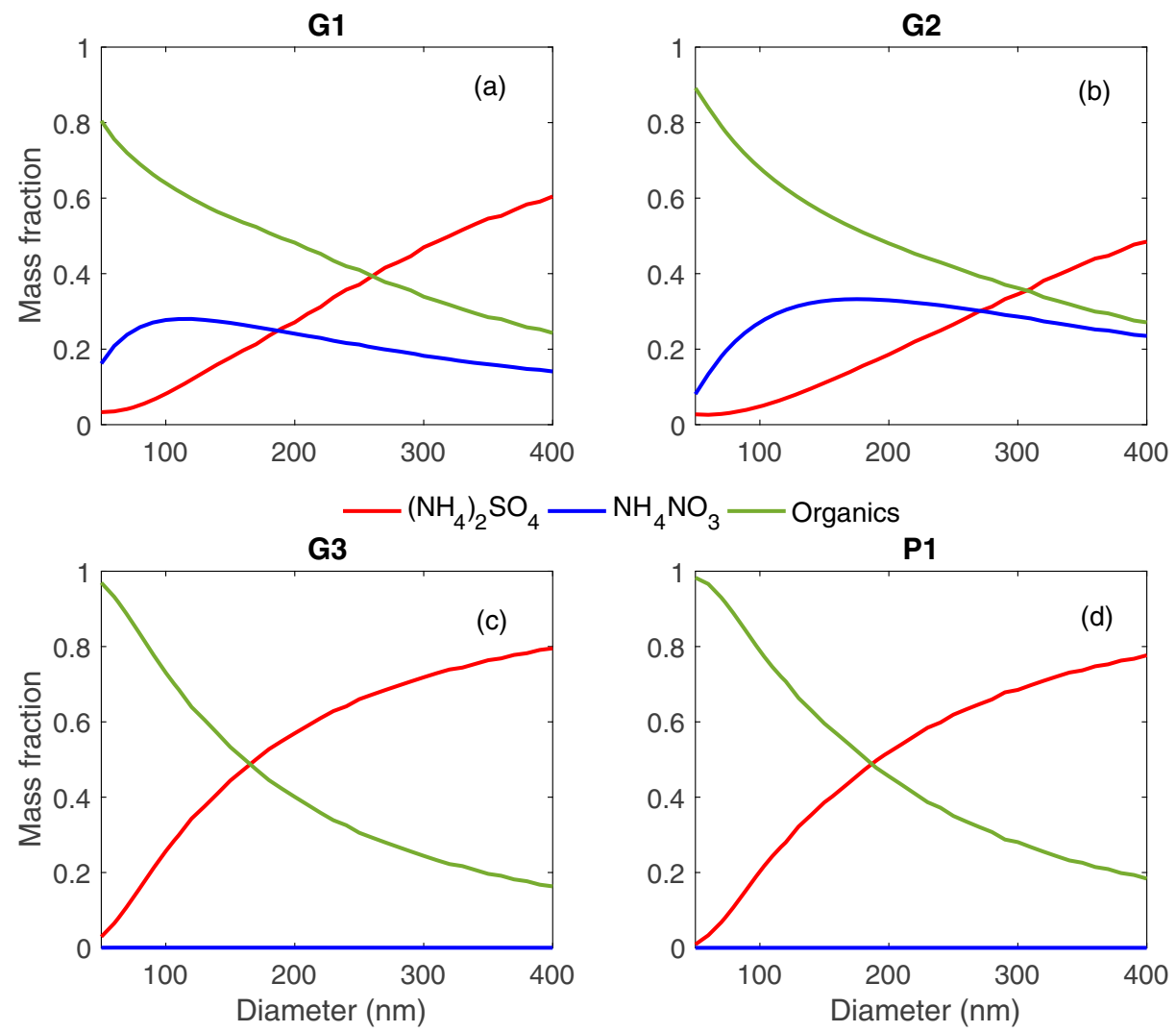

$\mathrm{NH}_{4} \mathrm{NO}_{3}=$ Organics

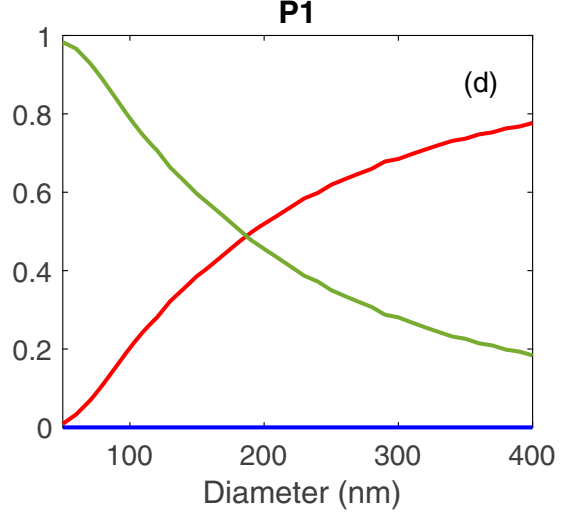

Fig. 2 Modelled size dependent ammoniumsulphate $\left(\left(\mathrm{NH}_{4}\right)_{2} \mathrm{SO}_{4}\right.$, red line $)$, ammoniumnitrate $\left(\mathrm{NH}_{4} \mathrm{NO}_{3}\right.$, blue line) and OA particle mass fractions (green line) for experiment G1, G2, G3 and P1 
In the literature, the average molar mass for SOA $\left(M_{S O A}\right)$ is in the range $\sim 0.15-0.48 \mathrm{~kg} \mathrm{~mol}^{-1}$ (e.g. Hallquist et al. 2009; Kuwata et al. 2013). In this study, $M_{S O A}$ is assumed a constant value of $0.2 \mathrm{~kg} \mathrm{~mol}^{-1}$, for all experiments. $M_{S O A}$ is a mean value adopted from Wittbom et al. (2014), obtained from model simulations of the gas-phase chemistry, SOA formation and composition using ADCHAM. The main precursors in all the experiments here are toluene, $p / m$-xylene and for the gasoline exhaust experiments, also $\mathrm{C}_{6}-\mathrm{C}_{9}$ light aromatics and naphtalenes contributed (Nordin et al. 2013). The molar masses for these three species are 0.092, 0.106 and $0.078 \mathrm{~kg} \mathrm{~mol}^{-1}$, respectively (the chemical composition of the undiluted gasoline exhaust can be found in the Supplement of Nordin et al. 2013). For the AS seed particles, the molar mass $\left(M_{A S}\right)$ is $0.132 \mathrm{~kg} \mathrm{~mol}^{-1}$ and for the AN produced during some of the experiments, the molar mass $\left(M_{A N}\right)$ is $0.080 \mathrm{~kg} \mathrm{~mol}^{-1}$ (Table 2).

For SOA, a density $\left(\rho_{\text {org }}\right)$ of $1400 \mathrm{~kg} \mathrm{~m}^{-3}$ was used in the Köhler calculations, derived from DMA-(TD)-APM density measurements of the aged particles in the experiments (,$G$ and P). The value is in agreement with previously reported densities of anthropogenic SOA formed from toluene and $m$-xylene (e.g. $1240-1450$ and $1330-1480 \mathrm{~kg} \mathrm{~m}^{-3}$; $\mathrm{Ng}$ et al. 2007). A primary particle density $\left(\rho_{\text {soot }}\right)$ of $1850 \mathrm{~kg} \mathrm{~m}^{-3}$ is used for the soot particles, in good agreement with other studies (e.g. $1770 \mathrm{~kg} \mathrm{~m}^{-3}$ (Park et al. 2004), $1840 \mathrm{~kg} \mathrm{~m}^{-3}$ (Choi et al. 1994), $1800 \mathrm{~kg} \mathrm{~m}^{-3}$ (Ristimaki et al. 2007) and $2000 \mathrm{~kg} \mathrm{~m}^{-3}$ (Park et al. 2003; Cross et al. 2007)). The crystal densities were used for AS $\left(\rho_{A S}=1770 \mathrm{~kg} \mathrm{~m}^{-3}\right)$ and $\operatorname{AN}\left(\rho_{A N}=1725 \mathrm{~kg} \mathrm{~m}^{-3}\right)$.

The van't Hoff factor $(i)$ is used to describe the water uptake and effect on water activity of a solute, i.e. a compound takes up water as if it would dissociate into $i$ number of ions and moles. Here, the organic fraction is treated as a compound that neither shows dissociation nor association in water, i.e. here the van't Hoff factor, $i_{\text {org }}=1$ (Svenningsson et al. 2006; Wittbom et al. 2014). For AS the van't Hoff factor $\left(i_{A S}\right)$ is approximated from experimental data according to Low (1969). For AN the van't Hoff factor $\left(i_{A N}\right)$, at subsaturation, is approximated from experimental data according to Chan et al. (1992) and at supersaturation $i_{A N}$ is set to a value of 2 (Svenningsson et al. 2006).

In this study, for the theoretical calculations using the modified Köhler theory, the organic fraction of the particle is modelled in a simplified way by separating the organic material into two fractions $\left(\beta_{1}\right.$ and $\left.\beta_{2}\right)$, where component 1 is fully soluble in water $\left(C_{s a t, l}=\infty\right)$ while

Table 2 Input values for CCN predictions. The values for SOA given here are independently retrieved from measurements, modelling and previous studies (see Wittbom et al. 2014 for details)

\begin{tabular}{llllll}
\hline & Water & SOA & AS & AN & BC \\
\hline$M\left(\mathrm{~kg} \mathrm{~mol}^{-1}\right)$ & 0.0182 & 0.2 & 0.132 & 0.0800 & 1725 \\
$\rho\left(\mathrm{kg} \mathrm{m}^{-3}\right)$ & 997.1 & 1400 & 1770 & $1.51-2^{\mathrm{b}}$ & 0 \\
$i$ & - & 1 & $2.38-2.43^{\mathrm{a}}$ & $0.072^{*}$ & \\
$\sigma\left(\mathrm{N} \mathrm{m}^{-1}\right)$ & 0.072 & $0.072^{*}$ & $0.072^{*}$ & & \\
$T(\mathrm{~K})$ & 298.15 & $\mathrm{c}$ & 767 & 2130 & 0.79 \\
$C_{\text {sat }}$ & & $0.13^{\mathrm{d}}$ & 0.56 & & 0 \\
$\kappa$
\end{tabular}

*In solution with water

${ }^{\text {a }}$ Fit to experimental data from Low (1969)

${ }^{\mathrm{b}}$ Fit to experimental data from Chan et al. (1992) for subsaturation, and $i_{A N}=2$ for supersaturation from Svenningsson et al. (2006)

${ }^{c}$ Asumptions made in the modified Köhler theory: Unlimited solubility of fraction $\beta_{1}$, for fraction $\beta_{2}$, see Table 4

${ }^{\mathrm{d}} \kappa_{\text {org }}$ (Eq. S7 with values from this table) 
component 2 has a limited solubility (with a set value of $C_{s a t, 2}$ ), i.e. part of $\beta_{2}$ will not go into solution. In reality, a combination of many different organics and solubilities are most likely to occur. The idea of this study is not to explicitly determine the values of $C_{s a t, 2}$ and/or $\beta_{2}$, but rather to demonstrate that there might be solubility limitations of the anthropogenic SOA, influencing the hygroscopicity of the particle. Therefore, $C_{s a t, 2}$ and $\beta_{2}$ are chosen to obtain best performance by the modified Köhler model. All data input for the Köhler model are listed in Table 2.

Quality control and limitations of the experimental and theoretical work performed in this study is listed in the Online Resource 1, section 5.

In this study we were not able to follow a given seed particle size, but selected the same total size implying that gradually smaller seed particle sizes were studied as the ageing proceeded (Fig. 3). When following a given seed particle, as in the atmosphere, condensation of soluble organic and inorganic material would increase the particle mass and is expected to decrease the critical supersaturation (Wittbom et al. 2014). The hygroscopic growth factor is a measure of the relative amount of water uptake and would under the same conditions either increase or decrease, depending on whether the condensing material is more or less hygroscopic compared to the seed. It is thus possible to observe decreasing hygroscopicity (or $\mathrm{K}$ values) with increasing SOA fractions even if the SOA contributes to water uptake. It just implicates that the SOA is not as hygroscopic as the seed, e.g. AS. The change in the seed particle size is accounted for in the Köhler modelling.

\section{Results and discussion}

\subsection{Experimental observations}

A decreasing trend for the hygroscopicity (decreasing $g f$ and increasing $s_{c}$ ) of the particles in the ammonium sulphate (AS) seed experiments (G and P) was observed, which can be explained by the fact that the size of the AS seed particles, connected with a given total size, decreases as more organic material condenses in the aerosol, i.e. the mass fraction of organic coating material increases and the mass fraction AS decreases in the particles. Figure 4 shows the data from experiment G3 (blue circles), as an example of AS seed particles coated with SOA produced from gasoline exhaust. The trends in hygroscopicity appear similar in all $\mathrm{G}$ and $\mathrm{P}$ experiments, i.e. the decrease in hygroscopicity for a given size depends on the amount of



\section{Time and particle progression}

Fig. 3 Selecting the same total particle size in the first DMA in the H-TDMA and in front of the CCN counter during the whole experiment implies that successively smaller seed particles are studied and in the case of AS seed, the contribution of AS on the total particle $\mathrm{K}$ values decreases 

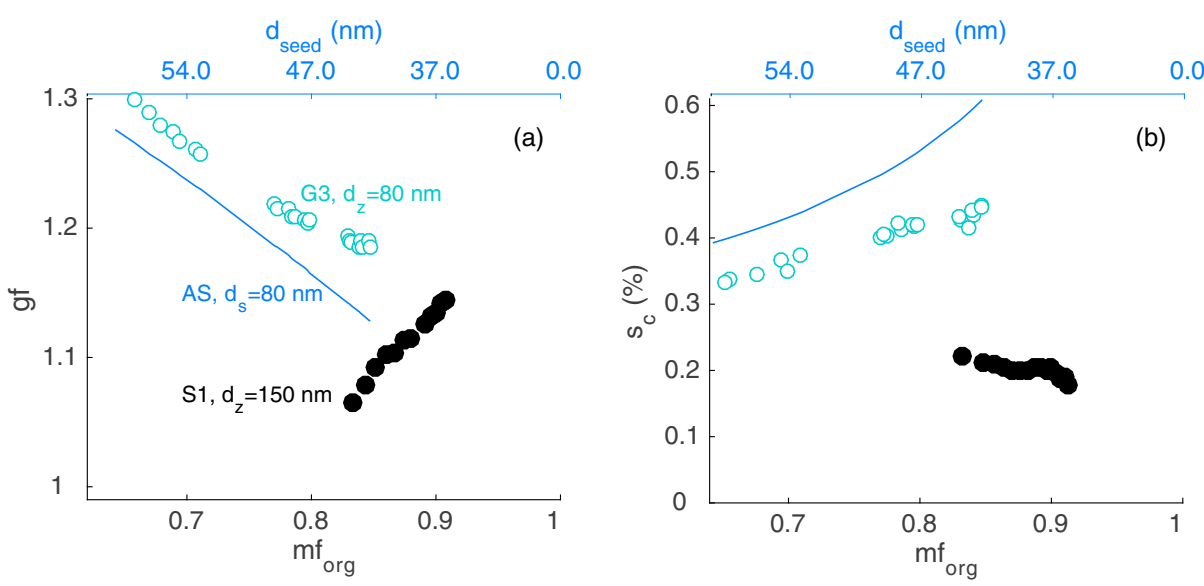

Fig. 4 The progression of (a) the $g f$ and (b) the $s_{c}$ with respect to increasing $\mathrm{mf}_{\text {org. }}$. Empirical data for the experiment using diesel soot as seed particles (S1, $d_{z}=150 \mathrm{~nm}$; black solid circles) or AS as seed particles (G3, $d_{z}=80 \mathrm{~nm}$; turquoise circles) are shown, as well as theoretical values for a particle with a total particle size of $d_{d r y}=80 \mathrm{~nm}$ and the amount of AS in the particle corresponds to the AS seed particle size $\left(d_{\text {seed }}\right)$ in the G3 experiment (blue line), hence a coated particle where only the AS is contributing to the water uptake . For comparison, a pure AS particle with $d_{z}=80 \mathrm{~nm}$ has a $g f=1.7$ and an $s_{c}=0.22$

organic material in relation to amount of inorganic salts (in experiment G1 and G2) in the particle. Also, shown in Fig. 4 are the expected growth factors and critical supersaturations for particles consisting of the actual seed particle amount of AS and an insoluble material. The fact that the experimental growth factors are higher and the supersaturations are lower compared to these theoretical calculations show that condensed material contributes to the hygroscopicity of the particles.

For the S experiments (soot seed particles), on the contrary, the hygroscopicity of the particles was observed to increase with increasing amount of condensing organic material. The increase in $g f$ and decrease in $s_{c}$ of the soot particles are exemplified in Fig. 4 by empirical data from experiment $\mathrm{S} 1$ (filled black circles). In the same way as for the $\mathrm{G}$ and $\mathrm{P}$ experiment, the size selection of the particles was performed after the smog chamber. Hence, the soot seed in the particle decreased for a selected total particle size during the experiment. The differences in the time evolution of the hygroscopicity, between the $\mathrm{G}$ and $\mathrm{P}$ experiments on one hand and the $\mathrm{S}$ experiments on the other, is expected and is mainly due to the difference in hygroscopicity of the seed particles used (AS particles in the G and P experiments, and soot agglomerates in the $\mathrm{S}$ experiments).

\section{$4.2 \kappa$ values at subsaturation and supersaturation}

The hygroscopicity parameter $\kappa$ is a parameter describing the particle affinity to water. Here, the $\kappa_{g f}$ and $\kappa_{s c}$ (for the whole particle) were derived from the measurements of $g f$ and $s_{c}$, respectively. The ranges of $\kappa$ values for the different experiments are listed in Table 3 . Generally, $\kappa$ increases for the $\mathrm{S}$ and decreases for the $\mathrm{G}$ and $\mathrm{P}$ experiments during the photochemical processing, starting with the $\kappa$ values of the seed particles (high for AS seed experiments, $\mathrm{G}$ and $\mathrm{P}$, and low for soot experiments, S) and approaching the $\kappa$ values for pure SOA as the particles becomes more SOA dominated. This change in $\kappa$ (hygroscopicity) is 
Table 3 Experimental details of the dry particle mobility diameter $\left(d_{z, d r y}\right)$, the critical supersaturation range measured by the two CCNC instruments $\left(s_{c}\right)$, measured growth factor $(g f)$ range derived from the H-TDMA, ranges in $\kappa$-values derived from $s_{c}$ and $g f\left(\kappa_{s c}\right.$ and $\kappa_{g f}$, respectively), as well as the ratio $\kappa_{g f} / \kappa_{s c}$

\begin{tabular}{|c|c|c|c|c|c|c|}
\hline Exp & $d_{z, d r y}[\mathrm{~nm}]$ & $s_{c}[\%]$ & $g f$ & $\begin{array}{l}\kappa_{s c} \\
\text { (range) }\end{array}$ & $\begin{array}{l}\kappa_{g f} \\
\text { (range) }\end{array}$ & $\kappa_{g f} / \kappa_{s c}$ (range) \\
\hline $\mathrm{S} 1$ & 150 & $0.19-0.21$ & $1.10-1.14$ & $0.09-0.11$ & $0.03-0.04$ & $0.27-0.41$ \\
\hline \multirow[t]{3}{*}{$\mathrm{S} 2$} & 90 & $0.40-0.41$ & 1.08 & $0.11-0.12$ & 0.04 & $0.34-0.36$ \\
\hline & 150 & $0.19-0.20$ & $1.08-1.10$ & $0.10-0.11$ & $0.04-0.05$ & $0.39-0.43$ \\
\hline & 300 & $0.08-0.09$ & $1.06-1.11$ & $0.07-0.09$ & $0.03-0.05$ & $0.36-0.69$ \\
\hline S3 & 60 & $0.81-0.84$ & $1.22-1.25$ & $0.09-0.10$ & 0.05 & $0.46-0.50$ \\
\hline $\mathrm{P} 1$ & 90 & $0.32-0.35$ & $1.24-1.26$ & $0.16-0.19$ & $0.11-0.12$ & $0.61-0.71$ \\
\hline \multirow[t]{2}{*}{ G1 (I1*) } & 80 & $0.32-0.34$ & 1.40 & $0.24-0.26$ & $0.23-0.24$ & $0.93-0.95$ \\
\hline & 100 & $0.21-0.22$ & $1.40-1.42$ & $0.28-0.31$ & $0.23-0.26$ & $0.76-0.91$ \\
\hline G2 (I2*) & 100 & 0.23 & 1.40 & $0.25-0.26$ & $0.22-0.23$ & $0.86-0.88$ \\
\hline \multirow[t]{2}{*}{ G3 (S1*) } & 80 & $0.33-0.44$ & $1.19-1.29$ & $0.14-0.25$ & $0.08-0.14$ & $0.55-0.61$ \\
\hline & 100 & 0.21 & 1.41 & 0.31 & 0.22 & 0.72 \\
\hline
\end{tabular}

*Corresponding experiment number in (Nordin et al. 2013)

expected, as discussed in Section 4.1, since the $\kappa$ value of the organic material is lower compared to those of the two inorganic salts in the particles (Table 2).

Theoretical calculations (using Eq. S6 and S7 in the Online Resource 1) show that for the SOA to affect the water uptake to the same extent as the AS (the inorganic salt in the seed particle) in the supersaturated regime, the SOA mass has to be a factor of $\sim 3.5$ larger than the AS mass, corresponding to an $\mathrm{mf}_{\text {org }}>0.78$, assuming that the organic material is fully soluble. In the subsaturated regime, similar theoretical calculations show that for the inorganic salt (AS) and the SOA to affect the water uptake to the same extent the SOA mass has to be a factor of 2.3 larger than the AS mass, or an $\mathrm{mf}_{\text {org }}>0.70$ is required. The values of $\mathrm{mf}_{\text {org }}$ differ between the regimes because $i_{A S}$ vary with molality.

In the end of the experiments, the $\kappa_{s c}$ head towards values of $\kappa_{s c}=0.14$ (AS seed, G and P, $\mathrm{mf}_{\text {org }}>0.9$ size dependant) and $\kappa_{s c}=0.12$ (soot seed, $\mathrm{S}, \mathrm{mf}_{\text {org }}>0.8$ size dependant). These final $\kappa_{s c}$ values are similar to $\kappa$ values observed in previous studies for anthropogenic SOA $(0-$ 0.13 for photochemically aged diesel soot, and $0.09-0.14$ for SOA from pure gas phase of the diesel vehicle; Tritscher et al. 2011;0.10-0.20, for anthropogenic SOA; Zhao et al. 2016). The $\kappa_{g f}$ is generally lower than the $\kappa_{s c}$, with final values of $\kappa_{g f}=$ 0.08 (AS seed) and $\kappa_{g f}=0.05$ (soot seed).

Indications of a size-dependent $\kappa$ (chemical composition) of the aerosol have been observed by others (e.g. Zhao et al. 2016), it can, however, neither be confirmed nor rejected from the observations in this study.

The gap between $\kappa_{g f}$ and $\kappa_{s c}$ is seen for all aerosol types in this study (all $\kappa_{g f}$ are below the 1:1 line in Fig. 5), and the gap is consistent with previous studies of anthropogenic SOA (e.g. Tritscher et al. 2011; Zhao et al. 2016). The lowest ratios of $\kappa_{g f} / \kappa_{s c}$ is seen for the $\mathrm{S}$ experiments and the highest ratios, closest to one, for the $\mathrm{G}$ experiments (Table 3). The variations in the $\kappa_{g f} / \kappa_{s c}$ ratio are influenced by the chemical composition of the particle, i.e. the gap between $\kappa_{g f}$ and $\kappa_{s c}$ suggests a mechanism leading to less water uptake in the subsaturated regime compared to the supersaturated regime depending on the SOA material. 


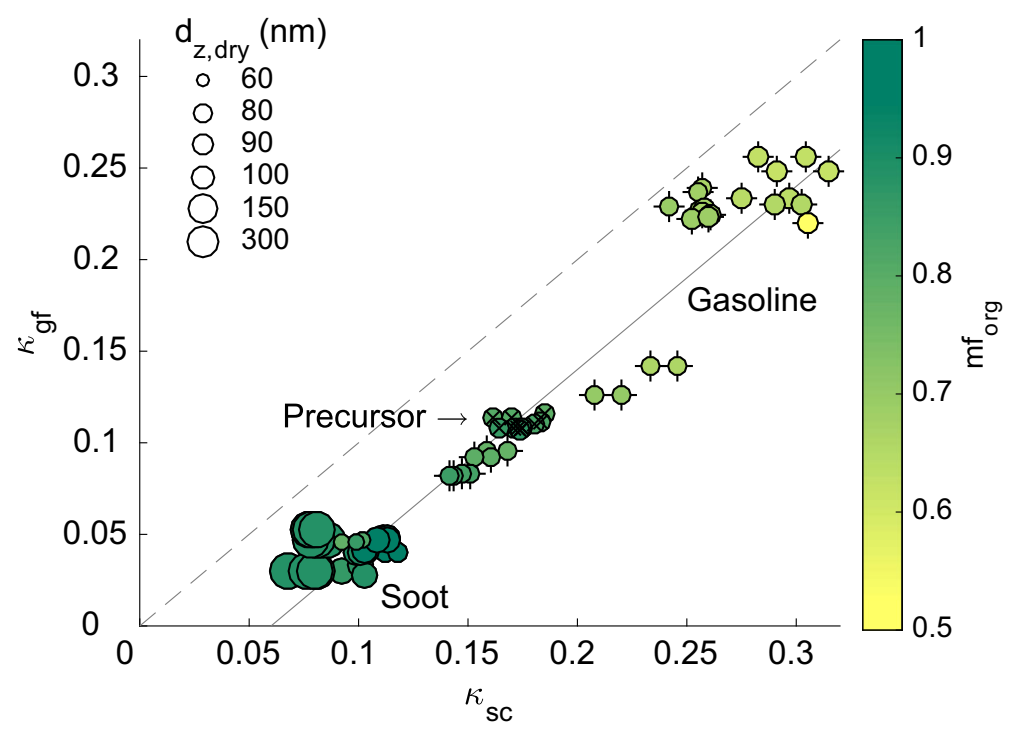

Fig. 5 Values of the $\kappa_{g f}$ compared to the $\kappa_{s c}$ derived from empirical $g f$ and $s_{c}$. The organic mass fraction $\left(\mathrm{mf}_{\mathrm{org}}\right)$ is indicated by color and $d_{z, d r y}(\mathrm{~nm})$ by size of the circle. All $\kappa_{g f}$ are lower compared to $\kappa_{s c}$, compare the dashed 1:1line with the solid line "to guide the eye". The S experiments (solid circles) are grouped at low $\kappa$ values $\left(\kappa_{g f}\right.$ $\sim 0.05$ ), while the $\mathrm{P}$ experiment (cross inside the circle) is at slightly higher $\kappa$ values $\left(\kappa_{g f} \sim 0.11\right)$. The $\mathrm{G}$ experiments (circles with plus behind) may be divided in two groups: G1 and G2 at $\kappa_{g f} \sim 0.24$, and G3 between $0.06<\kappa_{g f}<0.23$

\subsection{Comparing Köhler theory predictions with experimental data}

Köhler theory, together with information about particle composition, was used for predictions of the $s_{c}$ and $g f$, with three different approaches: (I) traditional Köhler-theory where the organic content is assumed to be fully soluble, (II) traditional Köhler theory where the organic content is assumed not soluble but wettable, and (III) modified Köhler theory where part of the organic material has a limited solubility. The predictions were compared to empirical data.

The results for approach I, assuming that the organic material in the particle is infinitely soluble, show that Köhler theory over-predicts the $g f$, with a deviation larger than the experimental errors for the $\mathrm{S}$ experiments that also has the highest normalised sum of square error, $e=0.0156$. However, it predicts the $s_{c}$ well, with only a slight under prediction (with $e<$ 0.0009 for all experiments), see Fig. $6 \mathrm{i}$ and Table 4.

With the assumption of insoluble but wettable organic material (approach II), the predicted hygroscopicities of the particles are lower compared to the measured, in both the subsaturated and supersaturated regimes (Fig. 6ii and Table 4). Hence, in applying this approach, when analysing the G and P experiments (gasoline and precursor), only AS and AN (produced in experiments G1 and G2) contribute to the hygroscopicity: compared to empirical data, predictions of the $s_{c}$ are in general slightly overestimated ( $e<0.0252$ for G and P experiments) while the $g f$ is slightly underestimated ( $e<0.0099$ for $\mathrm{G}$ and $\mathrm{P}$ experiments). For the $\mathrm{S}$ experiments the Kelvin effect determines the $s_{c}$ due to the assumption of insoluble but wettable organic material, i.e. only the size of the particle is of importance and the deviations between theoretical and experimental $s_{c}$ are large. In Fig. 6ii, for the $\mathrm{S}$ experiments, only the predicted value of $s_{c}(0.70 \%)$ for the largest size $\left(d_{z}=300 \mathrm{~nm}\right)$ is visible (compared to $\sim 0.081 \%$, experimentally determined), while the other measured sizes predicted $s_{c}$ values above the 


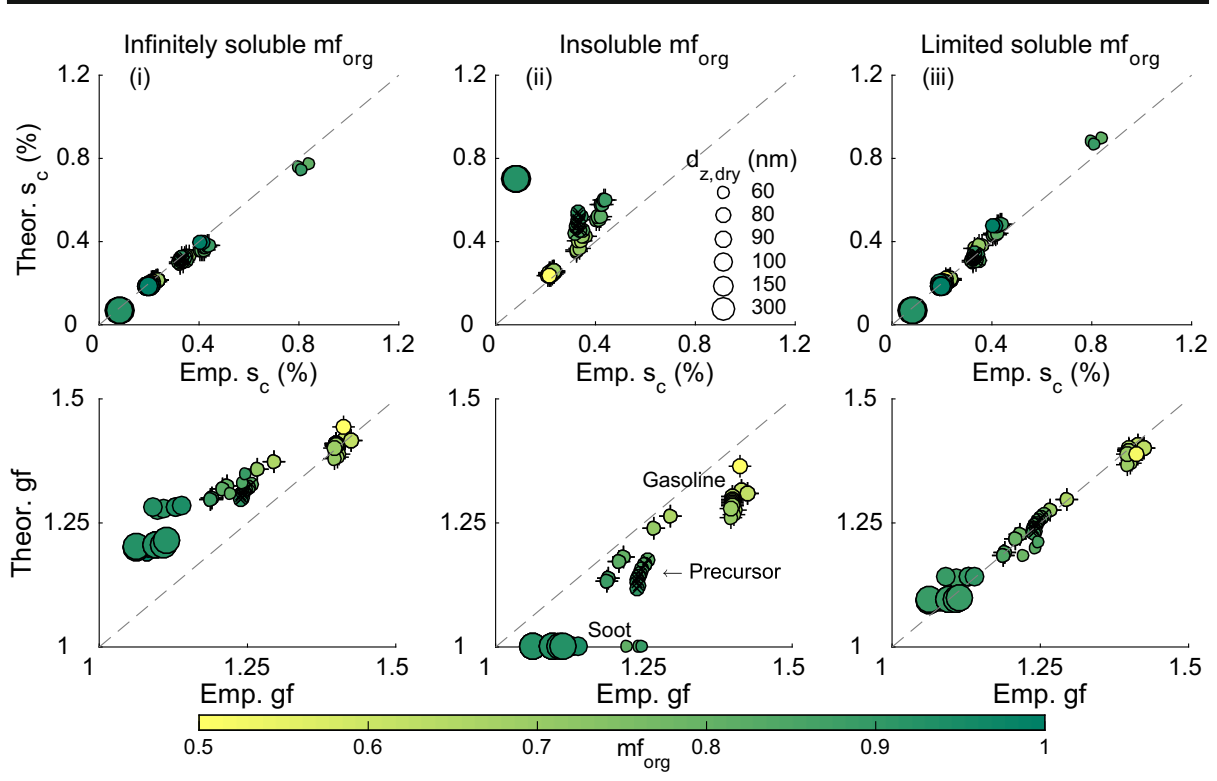

Fig. 6 Calculated vs. measured results, for $s_{c}$ and $g f$. In the Köhler predictions, three patterns are evident. (i) Predictions show higher hygroscopicity of the particles when all of the organic material is assumed to be infinitely soluble in water. (ii) When the organic fraction is not contributing to water uptake the predicted hygroscopicity of the particles is less than the measured. (iii) Best agreement between predictions and empirical data is acquired when part of the material has a limited solubility. The $d_{z}$ is indicated by marker size and $\mathrm{mf}_{\text {org }}$ is indicated by colour. The dashed line is the 1:1-line. In (ii, Theoretical $\left.s_{c}\right)$ only the largest soot particles $\left(d_{z}=\right.$ $300 \mathrm{~nm})$ are visible and the rest are outside the scale $\left(s_{c}>1.2 \%\right)$. In the subsaturated regime in (ii), the particles are wettable but not soluble and therefore they will not grow. The $\mathrm{S}$ experiments are denoted by circles, the $\mathrm{G}$ experiments are denoted by crosses behind circles, and the $\mathrm{P}$ experiment is denoted by crosses inside the circles

scale: for $d_{z}=60,90$, and $150 \mathrm{~nm}$ the predicted $s_{c}$ are approximately $3.57,2.36$, and $1.41 \%$, respectively, while the experimentally determined ones are $\sim 0.81, \sim 0.41, \sim 0.20 \%$ ( $_{\text {org }}$ dependant), respectively. Hence, for $s_{c}$ the error between model and experimental results are high, with $e_{s c}=1.1983$. For the soot particles, the approach II predicted $g f$ is equal to one, while empirical data show higher values $\left(e_{g f}=0.0143\right)$. Thus, using approach II, not enough

Table 4 The sum of the square error $(e)$ between measured $\left(g f_{\text {emp }}, s_{c, \text { emp }}\right)$ and predicted values $\left(g f_{\text {Theor }}, s_{c, \text { Theor }}\right)$, normalized to the number of data points $(n)$ used for each type of aerosol (G, P, S). Theoretical calculations using Köhler theory were performed assuming the organic material to be: (I) infinitely soluble, (II) insoluble but wettable, and (III) partly limited in solubility

\begin{tabular}{llllll}
\hline $\begin{array}{l}\text { Model error } \\
\left(e_{g f} \text { or } e_{s c}\right)\end{array}$ & $\begin{array}{l}\text { Aerosol } \\
\text { Type }\end{array}$ & $\begin{array}{l}n \text { (number } \\
\text { of data } \\
\text { points)* }\end{array}$ & $\begin{array}{l}\text { (I) Infinitely } \\
\text { soluble organic } \\
\text { material }\end{array}$ & $\begin{array}{l}\text { (II) Organic material } \\
\text { is insoluble but } \\
\text { wettable }\end{array}$ & $\begin{array}{l}\text { (III) Limited solubility } \\
\text { of part of the organic } \\
\text { material }\end{array}$ \\
\hline$e_{g f}=\frac{\sum\left(g f_{\text {emp }}-g f_{\text {Theor }}\right)^{2}}{n}$ & $\mathrm{G}$ & 30 & 0.00431 & 0.00790 & 0.00018 \\
& $\mathrm{P}$ & 11 & 0.00459 & 0.00987 & 0.00005 \\
$e_{s c}=\frac{\sum\left(S_{c, \text { emp }}-S_{c, \text { Theor }}\right)^{2}}{n}$ & $\mathrm{~S}$ & 29 & 0.01561 & 0.01432 & 0.00050 \\
& $\mathrm{G}$ & 30 & 0.00092 & 0.00584 & 0.00060 \\
& $\mathrm{P}$ & 11 & 0.00031 & 0.02515 & 0.00020 \\
& $\mathrm{~S}$ & 29 & 0.00049 & 1.81812 & 0.00103 \\
\hline
\end{tabular}

*Number of data points, where one data point is a mean value of 1-2 measurement points within 5-10 min of measurement 
soluble material (ions/molecules) contributes to the water vapour uptake in the theoretical predictions, especially for the $\mathrm{S}$ experiments.

Finally, applying approach III, in which the solubility and volume fraction of a compound with limited solubility are fitted to the data, modelled hygroscopicity ( $g f$ and $s_{c}$ ) more in line with the experimental data can be obtained, see Fig. 6iii. On average, approach III gives the smallest errors compared to empirical results $(e<0.0007$ for all experiments). Using this approach (unlike approach I and II), two model parameters $\left(C_{s a t, 2}\right.$ and $\left.\beta_{2}\right)$ were tuned for improving the agreement between predictions and measurements (Table 5). Accounting for solubility limitations means that, until enough water has condensed onto the particle, the number of moles dissolved in the droplet solution will be limited by the solubility of the compound and the amount of water. This is especially the case for particles in the subsaturated regime, where the amount of condensed water is lower. In these calculations, the organic fraction was adopted from the measurements with the DMA-(TD)-APM set-up (for experiments S), or modelled with input from the AMS and SMPS (for experiments G and P), see Section 3.2. Thereafter, the organic fraction was divided into two parts (fraction $\beta_{1}$ and $\beta_{2}$ ), with different amounts of the fully (component 1) and limitedly soluble (component 2) part depending on experiment. Fractions of compound 1 and 2 as well as the solubility of the fraction limited in solubility $\left(C_{\text {sat, } 2}\right)$ were tuned for each experiment (Table 5). The fitted sets of parameters do not represent unique solutions to the error minimisation and they can therefore be chosen in numerous ways.

It should be pointed out that differences between experiments might occur. For example, the two gasoline vehicles are not identical and probably produce SOA with different chemical and physical properties, as indicated by the ADCHAM model simulations (Table S1, Online Resource 1). Similarly, the SOA produced from the diesel vehicle and precursors (S1) was not the same as the SOA in the experiments where the flame soot generator was used (S2 and $\mathrm{S} 3$ ). During the photochemical ageing, a change of $C_{s a t, 2}$ cannot be ruled out. Also, the $\beta_{2}$ may progressively change during the experiments, which were not accounted for in this study. If the initial values of $\beta_{2}$ are high compared to later during the photochemical ageing, this could explain some of the high $s_{c}$ observed in the early measurements of S1 (Wittbom et al. 2014) as well as some of the discrepancies between the empirical data and predictions in this study.

The SOA solubility properties (e.g. the values of $\beta_{2}$ and $C_{s a t, 2}$ ) that provides the best solutions and fit to the empirical data, in both the subsaturated and supersaturated regimes, group according to the SOA precursors used in the experiments (see Table 5). The $\mathrm{S}$ experiments constitute one group, tuned to the highest values of $C_{s a t, 2}$. In the $\mathrm{S}$ experiments, SOA is primarily produced from the precursors added ( $m$-xylene and toluene), with soot agglomerates as seed particles. However, the gases in the vehicle exhaust or from the flame soot generator may also influence the SOA. The P experiment was tuned to somewhat lower

Table 5 Assigned values of organic fraction with limited solubility $\left(\beta_{2}\right)$ and the water solubility of this fraction $\left(C_{s a t, 2}\right)$

\begin{tabular}{llc}
\hline Experiment & $\beta_{2}$ & $C_{\text {sat, }}\left(\mathrm{g} \mathrm{l}^{-1}\right)$ \\
\hline S1 & 0.56 & 9 \\
S2 & 0.58 & 13 \\
S3 & 0.45 & 13 \\
P1 & 0.4 & 4 \\
G1 & 0.13 & 0.1 \\
G2 & 0.10 & 0.1 \\
G3 & 0.68 & 1 \\
\hline
\end{tabular}


values of $C_{s a t, 2}=4 \mathrm{~g}^{-1}$. For the $\mathrm{P}$ experiment, SOA is produced solely from the precursors and with AS particles as seed. No AN was produced during the $\mathrm{P}$ experiment. The lowest values of $C_{\text {sat,2 }}\left(0.1\right.$ and $\left.1 \mathrm{~g} \mathrm{l}^{-1}\right)$ were assigned to the gasoline experiments (G1 and G2).

SOA was in all $3 \mathrm{G}$ experiments produced from the gases in the gasoline exhaust and AS was used as seed particles. In experiments G1 and G2, the emissions were produced from a warm engine, whereas experiment G3 was a cold start experiment. As the three-way catalyst in the gasoline car heats up ammonia can form and be emitted (no ammonia emissions occur from the oxidation catalyst in the diesel car in S1). This allowed the formation of ammonium nitrate in experiment $\mathrm{G} 1$ and $\mathrm{G} 2$ but not in $\mathrm{G} 3$ and $\mathrm{S} 1$. The SOA properties from experiment $\mathrm{P}$ and G3 show similarities both in the ADCHAM and modified Köhler theory results.

According to Nordin et al. (2013), traditional light aromatic precursors could only explain $60 \%$ of the SOA mass produced in experiments G1 an G2, while in the cold start experiment (G3) light aromatic precursors could explain the majority of SOA. The additional SOA was interpreted to be caused by combustion generated SOA precursors from the warmer engine conditions in experiments G1 and G2 compared to the G3. The results from the cold start experiment were consistent with vaporised fuel being responsible for the SOA formation.

The three approaches are compared in Fig. 6 and Table 4. As shown in the figure, improved predictions of $s_{c}$ and $g f$ can be accomplished when it is assumed that part of the organic fraction has a limited solubility. To compare the three approaches, the model error $(e$, the sum of the square error between measured and predicted values, divided by the number of measurement points) was calculated, listed in Table 4 . The $e$ values of the different approaches clearly show that predictions of $g f$ and $s_{c}$ using approach III gives best agreement with empirical data, with the lowest values of $e$ in general. However, it should be noted that between the three approaches the differences in $e_{g f}$ are higher than the differences in $e_{s c}$. These higher differences support the assumption of an organic fraction that in part has a limited solubility $\left(\beta_{2}\right)$, i.e. a more pronounced effect of solubility limitations in the subsaturated than in the supersaturated regime. Also, a solubility limitation is observed for all experiments, with SOA produced from different anthropogenic precursors. These findings of solubility limitations, where the sparingly soluble compound gradually dissolves into the solution as dilution increases, are in agreement with e.g. Petters and Kreidenweis (2008).

The findings above (Fig. 6) suggest that solubility limitations in the water uptake of anthropogenic organic material are of importance in interpretations of laboratory studies and data from fresh aerosols dominated by single, or a few, sources of organic SOA precursors. During ambient atmospheric ageing, the particle will be influenced to a large extent by inorganic species, and the effect of the limited solubility of some SOA compounds on water uptake will probably be less pronounced.

\subsection{Surface tension reduction}

The discrepancy between $\kappa_{g f}$ and $\kappa_{s c}$ have been observed for SOA particles in the past and been discussed previously with regard to the surface tension $(\sigma)$ (e.g. Wex et al. 2009; Zhao et al. 2016). The surface tension may be reduced by surface-active organics, resulting in lower $s_{c}$ by lowering the Kelvin effect. Hence, a reduced surface tension increases the apparent $\kappa_{s c}$ value derived from measurements at supersaturation, while the $\kappa_{g f}$ determined at subsaturation will not be influenced to the same extent. Even though the organics in the droplets are more concentrated under the subsaturated condition, than under the supersaturated condition (Prisle et al. 2008), resulting in a lower surface tension in the 
subsaturated regime, the effect of a reduced surface tension is more pronounced in the determination of the critical supersaturation, $s_{c}$.

As a sensitivity test of the surface tension effects, calculations of the $\kappa$ values in this study were also performed in a simplified way with reduced surface tensions. We used constant values from 72 to $30 \mathrm{mN} / \mathrm{m}$, due to the fact that the variation of $\sigma$ with concentration is unknown (Fig. S12, Online Resource 1). The agreement in $\kappa$ values from the two regimes was improved with reduced surface tension. However, a surface tension reduction can only in part explain the discrepancy between the $\kappa$ values from the subsaturated and the supersaturated regimes in this study, in agreement with the conclusions of Wex et al. (2009). Furthermore, it will worsen the agreement between the $\kappa_{\text {chem }}$ values predicted from the chemical composition and those determined from hygroscopicity measurements, $\kappa_{s c}$ and $\kappa_{g f}$ since it would lower the theoretical $s_{c}$ (degrade the initially good agreement) and have a negligible effect on $g f$ predictions (that need to be improved). This is in accordance with the findings by McFiggans et al. (2006), that the over prediction of CCN and droplet numbers commonly found in closure studies are worsen if solely the surface tension is reduced.

\section{Conclusions and implications}

Anthropogenic SOA produced from four different precursor mixtures ((1) toluene and $m$ xylene, (2) Euro II diesel vehicle exhaust in addition to the precursors (1), (3) Euro II and (4) Euro IV gasoline-powered passenger vehicle exhaust), were photochemically processed in a smog chamber. The types of particles used as seed for SOA condensation included: exhaust particles from a diesel vehicle, particles from a flame soot generator, and AS particles.

Hygroscopic properties of the aged particles were measured in the subsaturated and supersaturated water vapour regimes, and $\kappa$ values were derived and compared for the two regimes. Generally, it can be noted that $\kappa$ values are lower for the S experiments (soot) than for the $\mathrm{G}$ and $\mathrm{P}$ experiments (gasoline and precursor), depending on the hygroscopicity of the seed particles. The results show a larger spread in $\kappa$ values within the $\mathrm{G}$ experiments. Also, it was clear that the amount of SOA affects the hygroscopicity of the particle: $\kappa$ increases for the soot particles and decreases for the AS particles with an increased organic mass fraction ( $\mathrm{mf}_{\mathrm{org}}$ ). Comparison of $\kappa_{s c}$ and $\kappa_{g f}$ show significant discrepancies for all experiments, with a ratio $\kappa_{g f} d$ $\kappa_{s c}$ around 0.8 for the gasoline experiments $(\mathrm{G}), 0.6$ for the precursor experiments $(\mathrm{P})$ and 0.4 for soot experiments (S). This gap between $\kappa_{s c}$ and $\kappa_{g f}$ can only in part be accounted for by assuming a reduced surface tension which also would lead to a worse agreement between $\kappa$ determined from chemical composition and those from our measurements, especially $\kappa_{s c}$.

Predictions of $s_{c}$ and $g f$ were calculated using three different approaches: (I) traditional Köhler theory where the organic content is assumed to be fully soluble, (II) traditional Köhler-theory where the organic content is assumed not to contribute to the hygroscopicity, and (III) modified Köhler-theory where part of the organic material has limited solubility. We show that Köhler-theory modified to account for a limited solubility (approach III) can explain the observed discrepancy between the $s_{c}$ and $g f$ in experimental data. These results indicate that part of the organic material produced from anthropogenic precursors have limited solubility, which affect the particles' ability to take up water. The limitation in water uptake is more pronounced in the subsaturated than in the supersaturated regime. This limitation can probably explain the gap between $\kappa_{s c}$ and $\kappa_{g f}$. 
Our results also indicate that the limited water uptake of anthropogenic SOA particles and its difference between humidity regimes, is most pronounce in aerosols dominated by one source. It could thus be especially important for large cities and vicinities abound with fresh organic particles of anthropogenic origin (e.g. Mexico City, Molina et al. 2010; Tokyo, Morino et al. 2014; Paris, Zhang et al. 2015). Furthermore, anthropogenic SOA from precursor emissions in large cities affects the atmospheric composition at regional scale according to modelling efforts (Zhang et al. 2015). Our results are also in line with studies in which predictions of $\mathrm{CCN}$ number concentrations have shown that an aerosol close to the pollution source requires more complex assumptions of organic mixing state/solubility and chemical composition, than an aerosol with a few hours of ageing or within a few tens of kilometres downwind of emission sources (e.g. Ervens et al. 2010; Molina et al. 2010 and references therein).

Acknowledgements This project has received funding from the Swedish Research Council (VR), the Swedish Research Council Formas, the Strategic Research Area ModElling the Regional and Global Earth system MERGE, ClimBEco research school (Lund University), the European Union's Horizon 2020 research and innovation programme under grant agreement No 654109, and the Nordic Top-level Research Initiative Cryosphere-atmosphere interactions in a changing Arctic climate - CRAICC.

Publisher's Note Springer Nature remains neutral with regard to jurisdictional claims in published maps and institutional affiliations.

Open Access This article is distributed under the terms of the Creative Commons Attribution 4.0 International License (http://creativecommons.org/licenses/by/4.0/), which permits unrestricted use, distribution, and reproduction in any medium, provided you give appropriate credit to the original author(s) and the source, provide a link to the Creative Commons license, and indicate if changes were made.

\section{References}

Bilde, M., Svenningsson, B.: CCN activation of slightly soluble organics: the importance of small amounts of inorganic salt and particle phase. Tellus B. 56(2), 128-134 (2004)

Budisulistiorini, S.H., Li, X., Bairai, S.T., Renfro, J., Liu, Y., Liu, Y.J., McKinney, K.A., Martin, S.T., McNeill, V.F., Pye, H.O.T., Nenes, A., Neff, M.E., Stone, E.A., Mueller, S., Knote, C., Shaw, S.L., Zhang, Z., Gold, A., Surratt, J.D.: Examining the effects of anthropogenic emissions on isoprene-derived secondary organic aerosol formation during the 2013 southern oxidant and aerosol study (SOAS) at the look rock, Tennessee ground site. Atmos. Chem. Phys. 15, 8871-8888 (2015)

Carlton, A.G., Pinder, R.W., Bhave, P.V., Pouliot, G.A.: To what extent can biogenic SOA be controlled? Environ. Sci. Technol. 44(9), 3376-3380 (2010)

Chan, C.K., Flagan, R.C., Seinfeld, J.H.: Water activities of Nh4no3/(Nh4)2so4 solutions. Atmos. Environ. Part a-General Topics. 26(9), 1661-1673 (1992)

Cheng, Z., Luo, L., Wang, S., Wang, Y., Sharma, S., Shimadera, H., Wang, X., Bressi, M., deMiranda, R.M., Jiang, J.: Status and characteristics of ambient PM2.5pollutionin global megacities. Environ. Int. 89, 212221 (2016)

Choi, M.Y., Hamins, A., Mulholland, G.W., Kashiwagi, T.: Simultaneous optical measurements of soot volume fraction and temperature in premixed flames. Combust. Flame. 99, 174-186 (1994)

Cross, E.S., Slowik, J.G., Davidovits, P., Allan, J.D., Worsnop, D.R., Jayne, J.T., Lewis, D.K., Canagaratna, M., Onasch, T.B.: Laboratory and ambient particle density determinations using light scattering in conjunction with aerosol mass spectrometry. Aerosol Sci. Technol. 41(4), 343-359 (Apr 2007)

De Gouw, J., Jimenez, J.L.: Organic aerosols in the Earth's atmosphere. Environ. Sci. Technol. 43(20), 7614 7618 (2009)

DeCarlo, P.F., Kimmel, J.R., Trimborn, A., Northway, M.J., Jayne, J.T., Aiken, A.C., Gonin, M., Fuhrer, K., Horvath, T., Docherty, K.S.: Field-deployable, high-resolution, time-of-flight aerosol mass spectrometer. Anal. Chem. 78(24), 8281-8289 (2006) 
Eriksson, A.C., Wittbom, C., Roldin, P., Sporre, M., Öström, E., Nilsson, P., Martinsson, J., Rissler, J., Nordin, E.Z., Svenningsson, B., Pagels, J., Swietlicki, E.: Diesel soot aging in urban plumes within hours under cold dark and humid conditions. Sci. Rep. 7(2017) Article Number: 12364), (2017). https://doi.org/10.1038 /s41598-017-12433-0

Ervens, B., Cubison, M.J., Andrews, E., Feingold, G., Ogren, J.A., Jimenez, J.L., Quinn, P.K., Bates, T.S., Wang, J., Zhang, Q., Coe, H., Flynn, M., Allan, J.D.: CCN predictions using simplified assumptions of organic aerosol composition and mixing state: a synthesis from six different locations. Atmos. Chem. Phys. 10(10), 4795-4807 (2010)

Fors, E.O., Rissler, J., Massling, A., Svenningsson, B., Andreae, M.O., Dusek, U., Frank, G.P., Hoffer, A., Bilde, M., Kiss, G., Janitsek, S., Henning, S., Facchini, M.C., Decesari, S., Swietlicki, E.: Hygroscopic properties of Amazonian biomass burning and European background HULIS and investigation of their effects on surface tension with two models linking H-TDMA to CCNC data. Atmos. Chem. Phys. 10(12), 5625-5639 (2010)

Fors, E.O., Swietlicki, E., Svenningsson, B., Kristensson, A., Frank, G.P., Sporre, M.: Hygroscopic properties of the ambient aerosol in southern Sweden - a two year study. Atmos. Chem. Phys. 11(16), 8343-8361 (2011)

Guenther, A.B., Jiang, X., Heald, C.L., Sakulyanontvittaya, T., Duhl, T., Emmons, L.K., Wang, X.: The model of emissions of gases and aerosols from Nature version 2.1 (MEGAN2.1): an extended and updated framework for modeling biogenic emissions. Geosci. Model Dev. 5(6), 1471-1492 (2012). https://doi.org/10.5194/gmd5-1471-2012

Hallquist, M., Wenger, J., Baltensperger, U., Rudich, Y., Simpson, D., Claeys, M., Dommen, J., Donahue, N., George, C., Goldstein, A.: The formation, properties and impact of secondary organic aerosol: current and emerging issues. Atmos. Chem. Phys. 9(14), 5155-5236 (2009)

Henning, S., Ziese, M., Kiselev, A., Saathoff, H., Möhler, O., Mentel, T.F., Buchholz, A., Spindler, C., Michaud, V., Monier, M., Sellegri, K., Stratmann, F.: Hygroscopic growth and droplet activation of soot particles: uncoated, succinic or sulfuric acid coated. Atmos. Chem. Phys. 12(10), 4525-4537 (2012)

Henze, D.K., Seinfeld, J.H., Ng, N.L., Kroll, J.H., Fu, T.M., Jacob, D.J., Heald, C.L.: Global modeling of secondary organic aerosol formation from aromatic hydrocarbons: high- vs. low-yield pathways. Atmos. Chem. Phys. 8(9), 2405-2420 (2008)

Huff Hartz, K.E., Rosenørn, T., Ferchak, S.R., Raymond, T.M., Bilde, M., Donahue, N.M., Pandis, S.N.: Cloud condensation nuclei activation of monoterpene and sesquiterpene secondary organic aerosol. J. Geophys. Res. Atmos. 110(2005), D14 (2005). https://doi.org/10.1029/2004JD005754

IPCC. IPCC 2013: Climate Change 2013: The Physical Science Basis. Working Group I Contribution to the IPCC 5th Assessment Report - Changes to the Underlying Scientific/Technical Assessment (IPCC-XXVI/ Doc.4). (2013). http://www.ipcc.ch/report/ar5/wg1/ (2013). Accessed 6 August 2015

IPCC. IPCC 2014: Summary for policymakers. In Climate Change 2014: Impacts, Adaptation, and Vulnerability. Part A: Global and Sectoral Aspects. Contribution of Working Group II to the Fifth Assessment Report of the Intergovernmental Panel on Climate Change, edited by C. B. Field, V. R. Barros, D. J. Dokken, K. J. Mach, M. D. Mastrandrea, T. E. Bilir, M. Chatterjee, K. L. Ebi, Y. O. Estrada, R. C. Genova, B. Girma, E. S. Kissel, A. N. Levy, S. MacCracken, P. R. Mastrandrea and L. L. White, 1-32. Cambridge University Press, Cambridge, United Kingdom and New York, NY, USA, (2014). https:/www.ipcc.ch/pdf/assessmentreport/ar5/wg2/ar5_wgII_spm_en.pdf(2014). Accessed 6 August 2015

Jimenez, J.L., Canagaratna, M.R., Donahue, N.M., Prevot, A.S.H., Zhang, Q., Kroll, J.H., DeCarlo, P.F., Allan, J.D., Coe, H., Ng, N.L., Aiken, A.C., Docherty, K.S., Ulbrich, I.M., Grieshop, A.P., Robinson, A.L., Duplissy, J., Smith, J.D., Wilson, K.R., Lanz, V.A., Hueglin, C., Sun, Y.L., Tian, J., Laaksonen, A., Raatikainen, T., Rautiainen, J., Vaattovaara, P., Ehn, M., Kulmala, M., Tomlinson, J.M., Collins, D.R., Cubison, M.J., Dunlea, E.J., Huffman, J.A., Onasch, T.B., Alfarra, M.R., Williams, P.I., Bower, K., Kondo, Y., Schneider, J., Drewnick, F., Borrmann, S., Weimer, S., Demerjian, K., Salcedo, D., Cottrell, L., Griffin, R., Takami, A., Miyoshi, T., Hatakeyama, S., Shimono, A., Sun, J.Y., Zhang, Y.M., Dzepina, K., Kimmel, J.R., Sueper, D., Jayne, J.T., Herndon, S.C., Trimborn, A.M., Williams, L.R., Wood, E.C., Middlebrook, A.M., Kolb, C.E., Baltensperger, U., Worsnop, D.R.: Evolution of organic aerosols in the atmosphere. Science. 326(5959), 1525-1529 (2009)

Kanakidou, M., Seinfeld, J.H., Pandis, S.N., Barnes, I., Dentener, F.J., Facchini, M.C., Van Dingenen, R., Ervens, B., Nenes, A., Nielsen, C.J., Swietlicki, E., Putaud, J.P., Balkanski, Y., Fuzzi, S., Horth, J., Moortgat, G.K., Winterhalter, R., Myhre, C.E.L., Tsigaridis, K., Vignati, E., Stephanou, E.G., Wilson, J.: Organic aerosol and global climate modelling: a review. Atmos. Chem. Phys. 5, 1053-1123 (2005)

Khalizov, A.F., Zhang, R.Y., Zhang, D., Xue, H.X., Pagels, J., McMurry, P.H.: Formation of highly hygroscopic soot aerosols upon internal mixing with sulfuric acid vapor. J. Geophys. Res. Atmos. 114, (2009)

Kuwata, M., Shao, W., Lebouteiller, R., Martin, S.T.: Classifying organic materials by oxygen-to-carbon elemental ratio to predict the activation regime of cloud condensation nuclei (CCN). Atmos. Chem. Phys. 13(10), 5309-5324 (2013) 
Lance, S., Medina, J., Smith, J.N., Nenes, A.: Mapping the operation of the DMT continuous flow CCN counter. Aerosol Sci. Technol. 40(4), 242-254 (2006)

Liu, S., Aiken, A.C., Gorkowski, K., Dubey, M.K., Cappa, C.D., Williams, L.R., Herndon, S.C., Massoli, P., Fortner, E.C., Chhabra, P.S., Brooks, W.A., Onasch, T.B., Jayne, J.T., Worsnop, D.R., China, S., Sharma, N., Mazzoleni, C., Xu, L., Ng, N.L., Liu, D., Allan, J.D., Lee, J.D., Fleming, Z.L., Mohr, C., Zotter, P., Szidat, S., Prevot, A.S.H.: Enhanced light absorption by mixed source black and brown carbon particles in UK winter. Nat. Commun. 6, 8435 (2015)

Löndahl, J., Pagels, J., Boman, C., Swietlicki, E., Massling, A., Rissler, J., Blomberg, A., Bohgard, M., Sandström, T.: Deposition of biomass combustion aerosol particles in the human respiratory tract. Inhal. Toxicol. 20(10), 923-933 (2008)

Low, R.: A theoretical study of nineteen condensation nuclei. J. Rech. Atmosph. 4, 65-78 (1969)

Malik, A., Abdulhamid, H., Pagels, J., Rissler, J., Lindskog, M., Nilsson, P., Bjorklund, R., Jozsa, P., Visser, J., Spetz, A., Sanati, M.: A potential soot mass determination method from resistivity measurement of thermophoretically deposited soot. Aerosol Sci. Technol. 45(2), 284-294 (2011)

Martin, M., Tritscher, T., Juranyi, Z., Heringa, M.F., Sierau, B., Weingartner, E., Chirico, R., Gysel, M., Prevot, A.S.H., Baltensperger, U., Lohmann, U.: Hygroscopic properties of fresh and aged wood burning particles. J. Aerosol Sci. 56, 15-29 (Feb 2013)

McFiggans, G., Artaxo, P., Baltensperger, U., Coe, H., Facchini, M.C., Feingold, G., Fuzzi, S., Gysel, M., Laaksonen, A., Lohmann, U., Mentel, T.F., Murphy, D.M., O'Dowd, C.D., Snider, J.R., Weingartner, E.: The effect of physical and chemical aerosol properties on warm cloud droplet activation. Atmos. Chem. Phys. 6, 2593-2649 (2006)

McMurry, P.H., Wang, X., Park, K., Ehara, K.: The relationship between mass and mobility for atmospheric particles: a new technique for measuring particle density. Aerosol Sci. Technol. 36(2), 227-238 (2002)

Molina, L.T., Madronich, S., Gaffney, J.S., Apel, E., de Foy, B., Fast, J., Ferrare, R., Herndon, S., Jimenez, J.L., Lamb, B., Osornio-Vargas, A.R., Russell, P., Schauer, J.J., Stevens, P.S., Volkamer, R., Zavala, M.: An overview of the MILAGRO 2006 campaign: Mexico City emissions and their transport and transformation. Atmos. Chem. Phys. 10(18), 8697-8760 (2010)

Moore, R.H., Nenes, A.: Scanning flow CCN analysis - a method for fast measurements of CCN spectra. Aerosol Sci. Technol. 43(12), 1192-1207 (2009)

Morino, Y., Tanabe, K., Sato, K., Ohara, T.: Secondary organic aerosol model intercomparison based on secondary organic aerosol to odd oxygen ratio in Tokyo. J. Geophys. Res. Atmos. 119(23), 13489-13505 (2014)

Ng, N.L., Kroll, J.H., Chan, A.W.H., Chhabra, P.S., Flagan, R.C., and Seinfeld, J.H.: Secondary organic aerosol formation from m-xylene, toluene, and benzene. Atmos. Chem. Phys. 7, 3909-3922 (2007)

Nilsson, E., Swietlicki, E., Sjogren, S., Löndahl, J., Nyman, M., Svenningsson, B.: Development of an H-TDMA for long-term unattended measurement of the hygroscopic properties of atmospheric aerosol particles. Atmos. Meas. Tech. 2(1), 313-318 (2009)

Nordin, E.Z., Eriksson, A.C., Roldin, P., Nilsson, P.T., Carlsson, J.E., Kajos, M.K., Hellén, H., Wittbom, C., Rissler, J., Löndahl, J., Swietlicki, E., Svenningsson, B., Bohgard, M., Kulmala, M., Hallquist, M., Pagels, J.H.: Secondary organic aerosol formation from idling gasoline passenger vehicle emissions investigated in a smog chamber. Atmos. Chem. Phys. 13(12), 6101-6116 (2013)

Onasch, T., Trimborn, A., Fortner, E., Jayne, J., Kok, G., Williams, L., Davidovits, P., Worsnop, D.: Soot particle aerosol mass spectrometer: development, validation, and initial application. Aerosol Sci. Technol. 46(7), 804-817 (2012)

Pagels, J., Khalizov, A.F., McMurry, P.H., Zhang, R.Y.: Processing of soot by controlled Sulphuric acid and water condensation mass and mobility relationship. Aerosol Sci. Technol. 43(7), 629-640 (2009)

Park, K., Cao, F., Kittelson, D.B., McMurry, P.H.: Relationship between particle mass and mobility for diesel exhaust particles. Environ. Sci. Technol. 37(3), 577-583 (2003)

Park, K., Kittelson, D.B., Zachariah, M.R., McMurry, P.H.: Measurement of inherent material density of nanoparticle agglomerates. J. Nanopart. Res. 6(2-3), 267-272 (2004)

Peng, J.F., Hu, M., Guo, S., Du, Z.F., Zheng, J., Shang, D.J., Zamora, M.L., Zeng, L.M., Shao, M., Wu, Y.S., Zheng, J., Wang, Y., Glen, C.R., Collins, D.R., Molina, M.J., Zhang, R.Y.: Markedly enhanced absorption and direct radiative forcing of black carbon under polluted urban environments. PNAS. 113(16), 4266-4271 (2016). https://doi.org/10.1073/pnas.1602310113

Petters, M., Kreidenweis, S.: A single parameter representation of hygroscopic growth and cloud condensation nucleus activity. Atmos. Chem. Phys. 7(8), 1961-1971 (2007)

Petters, M., Kreidenweis, S.: A single parameter representation of hygroscopic growth and cloud condensation nucleus activity-part 2: including solubility. Atmos. Chem. Phys. 8(20), 6273-6279 (2008) 
Petters, M.D., Kreidenweis, S.M.: A single parameter representation of hygroscopic growth and cloud condensation nucleus activity - part 3: including surfactant partitioning. Atmos. Chem. Phys. 13(2), 1081-1091 (2013)

Petters, M.D., Wex, H., Carrico, C.M., Hallbauer, E., Massling, A., McMeeking, G.R., Poulain, L., Wu, Z., Kreidenweis, S.M., Stratmann, F.: Towards closing the gap between hygroscopic growth and activation for secondary organic aerosol - part 2: theoretical approaches. Atmos. Chem. Phys. 9(12), 3999-4009 (2009)

Prisle, N.L., Raatikainen, T., Sorjamaa, R., Svenningsson, B., Laaksonen, A., Bilde, M.: Surfactant partitioning in cloud droplet activation: a study of C8, C10, C12 and C14 normal fatty acid sodium salts. Tellus Series BChem. Phys. Met. 60(3), 416-431 (2008). https://doi.org/10.1111/j.1600-0889.2008.00352.x

Rissler, J., Vestin, A., Swietlicki, E., Fisch, G., Zhou, J., Artaxo, P., Andreae, M.O.: Size distribution and hygroscopic properties of aerosol particles from dry-season biomass burning in Amazonia. Atmos. Chem. Phys. 6, 471-491 (2006)

Rissler, J., Swietlicki, E., Bengtsson, A., Boman, C., Pagels, J., Sandström, T., Blomberg, A., Löndahl, J.: Experimental determination of deposition of diesel exhaust particles in the human respiratory tract. J. Aerosol Sci. 48, 18-33 (2012)

Rissler, J., Messing, M.E., Malik, A.I., Nilsson, P.T., Nordin, E.Z., Bohgard, M., Sanati, M., Pagels, J.H.: Effective density characterization of soot agglomerates from various sources and comparison to aggregation theory. Aerosol Sci. Technol. 47(7), 792-805 (2013)

Ristimaki, J., Vaaraslahti, K., Lappi, M., Keskinen, J.: Hydrocarbon condensation in heavy-duty diesel exhaust. Environ. Sci. Technol. 41(18), 6397-6402 (2007)

Roberts, G.C., Nenes, A.: A continuous-flow Streamwise thermal-gradient CCN chamber for atmospheric measurements. Aerosol Sci. Technol. 39(3), 206-221 (2005)

Roldin, P., Eriksson, A.C., Nordin, E.Z., Hermansson, E., Mogensen, D., Rusanen, A., Boy, M., Swietlicki, E., Svenningsson, B., Zelenyuk, A., Pagels, J.: Modelling non-equilibrium secondary organic aerosol formation and evaporation with the aerosol dynamics, gas- and particle-phase chemistry kinetic multilayer model ADCHAM. Atmos. Chem. Phys. 14(15), 7953-7993 (2014)

Ruehl, C.R., Chuang, P.Y., Nenes, A.: Aerosol hygroscopicity at high (99 to 100\%) relative humidities. Atmos. Chem. Phys. 10(3), 1329-1344 (2010)

Schauer, J.J., Kleeman, M.J., Cass, G.R., Simoneit, B.R.T.: Measurement of emissions from air pollution sources. 2. C-1 through C-30 organic compounds from medium duty diesel trucks. Environ. Sci. Technol. 33(10), $1578-1587$ (1999)

Schauer, J.J., Kleeman, M.J., Cass, G.R., Simoneit, B.R.T.: Measurement of emissions from air pollution sources. 5. C-1-C-32 organic compounds from gasoline-powered motor vehicles. Environ. Sci. Technol. 36(6), 11691180 (2002)

Shilling, J.E., Zaveri, R.A., Fast, J.D., Kleinman, L., Alexander, M.L., Canagaratna, M.R., Fortner, E., Hubbe, J.M., Jayne, J.T., Sedlacek, A., Setyan, A., Springston, S., Worsnop, D.R., Zhang, Q.: Enhanced SOA formation from mixed anthropogenic and biogenic emissions during the CARES campaign. Atmos. Chem. Phys. 13(4), 2091-2113 (2013)

Shulman, M.L., Jacobson, M.C., Charlson, R.J., Synovec, R.E., Young, T.E.: Dissolution behavior and surface tension effects of organic compounds in nucleating cloud droplets (1996). Geophys. Res. Letters. 23(5), 603-603 (1996). https://doi.org/10.1029/95GL03810

Singh, N., Murari, V., Kumar, M., Barman, S.C., Banerjee, T.: Fine particulates over South Asia: review and meta-analysis of PM2,5 aource apportionment through receptor model. Environ. Pollut. 223, 121-136 (2017)

Spracklen, D.V., Carslaw, K.S., Poschl, U., Rap, A., Forster, P.M.: Global cloud condensation nuclei influenced by carbonaceous combustion aerosol. Atmos. Chem. Phys. 11(17), 9067-9087 (2011a)

Spracklen, D.V., Jimenez, J.L., Carslaw, K.S., Worsnop, D.R., Evans, M.J., Mann, G.W., Zhang, Q., Canagaratna, M.R., Allan, J., Coe, H., McFiggans, G., Rap, A., Forster, P.: Aerosol mass spectrometer constraint on the global secondary organic aerosol budget. Atmos. Chem. Phys. 11(23), 12109-12136 (2011b)

Svenningsson, B., Rissler, J., Swietlicki, E., Mircea, M., Bilde, M., Facchini, M.C., Decesari, S., Fuzzi, S., Zhou, J., Monster, J., Rosenorn, T.: Hygroscopic growth and critical supersaturations for mixed aerosol particles of inorganic and organic compounds of atmospheric relevance. Atmos. Chem. Phys. 6, 1937-1952 (2006)

Tritscher, T., Jurányi, Z., Martin, M., Chirico, R., Gysel, M., Heringa, M.F., DeCarlo, P.F., Sierau, B., Prévôt, A.S.H., Weingartner, E., Baltensperger, U.: Changes of hygroscopicity and morphology during ageing of diesel soot. Environ. Res. Letters. 6(3), 034026 (2011)

Wex, H., Petters, M.D., Carrico, C.M., Hallbauer, E., Massling, A., McMeeking, G.R., Poulain, L., Wu, Z., Kreidenweis, S.M., Stratmann, F.: Towards closing the gap between hygroscopic growth and activation for secondary organic aerosol: part 1-evidence from measurements. Atmos. Chem. Phys. 9(12), 3987-3997 (2009) 
WHO: WHO Releases Country Estimates on Air Pollution Exposure and Health Impact. World Health Organization, Geneva (2016) http:/www.who.int/mediacentre/news/releases/2016/air-pollutionestimates/en/ (2016). Accessed 27 September 2016

Wittbom, C., Eriksson, A.C., Rissler, J., Carlsson, J.E., Roldin, P., Nordin, E.Z., Nilsson, P.T., Swietlicki, E., Pagels, J.H., Svenningsson, B.: Cloud droplet activity changes of soot aerosol upon smog chamber ageing. Atmos. Chem. Phys. 14(18), 9831-9854 (2014)

Zhang, Q.J., Beekmann, M., Freney, E., Sellegri, K., Pichon, J.M., Schwarzenboeck, A., Colomb, A., Bourrianne, T., Michoud, V., Borbon, A.: Formation of secondary organic aerosol in the Paris pollution plume and its impact on surrounding regions. Atmos. Chem. Phys. 15(24), 13973-13992 (2015)

Zhao, D.F., Buchholz, A., Kortner, B., Schlag, P., Rubach, F., Kiendler-Scharr, A., Tillmann, R., Wahner, A., Flores, J.M., Rudich, Y., Watne, Å.K., Hallquist, M., Wildt, J., Mentel, T.F.: Size-dependent hygroscopicity parameter (K) and chemical composition of secondary organic cloud condensation nuclei. Geophys. Res. Letters. 42(24), 10,920-10,928 (2015)

Zhao, D.F., Buchholz, A., Kortner, B., Schlag, P., Rubach, F., Fuchs, H., Kiendler-Scharr, A., Tillmann, R., Wahner, A., Watne, Å.K., Hallquist, M., Flores, J.M., Rudich, Y., Kristensen, K., Hansen, A.M.K., Glasius, M., Kourtchev, I., Kalberer, M., Mentel, T.F.: Cloud condensation nuclei activity, droplet growth kinetics, and hygroscopicity of biogenic and anthropogenic secondary organic aerosol (SOA). Atmos. Chem. Phys. 16(2), 1105-1121 (2016)

\section{Affiliations}

\section{Wittbom ${ }^{1,2}$ - A. C. Eriksson ${ }^{3}$ - J. Rissler ${ }^{3,4}$ • P. Roldin ${ }^{1}$ • E. Z. Nordin ${ }^{3,5}$ • S. Sjogren ${ }^{1,6}$. P. T. Nilsson ${ }^{3} \cdot$ E. Swietlicki ${ }^{1} \cdot$ J. Pagels $^{3} \cdot$ B. Svenningsson ${ }^{1}$}

1 Department of Physics, Lund University, P.O. Box 118, 22100 Lund, SE, Sweden

2 Skåne Association of Local Authorities, Lund, Sweden

3 Ergonomics and Aerosol Technology, Lund University, P.O. Box 118, 22100 Lund, SE, Sweden

4 Chemistry, Materials and Surfaces, RISE Research Institutes of Sweden, 22370 Lund, Sweden

5 Sweco Environment, Helsingborg, Sweden

6 University of Applied Sciences Northwestern Switzerland, Brugg-Windisch, Switzerland 